\title{
UHPLC-MS Chemical Fingerprinting and Antioxidant, Antiproliferative, and Enzyme Inhibition Potential of Gaultheria pumila Berries
}

\author{
Carlos Fernández-Galleguillos ${ }^{1}$, Luisa Quesada-Romero ${ }^{2, *}$, Adrián Puerta ${ }^{3}$, José M. Padrón ${ }^{3}$ D, Ernane Souza ${ }^{4}$, \\ Javier Romero-Parra ${ }^{5}$ and Mario J. Simirgiotis ${ }^{1,6, *(D)}$
}

1 Instituto de Farmacia, Facultad de Ciencias, Universidad Austral de Chile, Campus Isla Teja, Valdivia 5090000, Chile; carlos.fernandez@uach.cl

2 Facultad de Ciencias Para el Cuidado de la Salud, Universidad San Sebastián, Valdivia 5090000, Chile

3 BioLab, Instituto Universitario de Bio-Orgánica Antonio González (IUBO-AG), Universidad de La Laguna, 38206 La Laguna, Spain; apuertaa@ull.es (A.P.); jmpadron@ull.es (J.M.P.)

4 The Lloyd L. Gregory School of Pharmacy, Palm Beach Atlantic University, West Palm Beach, FL 33401, USA; ernane.souza@pba.edu

5 Departamento de Química Orgánica y Fisicoquímica, Facultad de Ciencias Químicas y Farmacéuticas, Universidad de Chile, Olivos 1007, Casilla 233, Santiago 6640022, Chile; javier.romero@ciq.uchile.cl

6 Center for Interdisciplinary Studies on the Nervous System (CISNe), Universidad Austral de Chile, Valdivia 5090000, Chile

Citation: Fernández-Galleguillos, C.; Quesada-Romero, L.; Puerta, A.;

Padrón, J.M.; Souza, E.;

Romero-Parra, J.; Simirgiotis, M.J. UHPLC-MS Chemical Fingerprinting and Antioxidant, Antiproliferative, and Enzyme Inhibition Potential of Gaultheria pumila Berries. Metabolites 2021, 11, 523. https://doi.org/ $10.3390 /$ metabo11080523

Academic Editor: Hirokazu Kawagishi

Received: 19 July 2021

Accepted: 3 August 2021

Published: 7 August 2021

Publisher's Note: MDPI stays neutral with regard to jurisdictional claims in published maps and institutional affiliations.

Copyright: (c) 2021 by the authors. Licensee MDPI, Basel, Switzerland. This article is an open access article distributed under the terms and conditions of the Creative Commons Attribution (CC BY) license (https:/ / creativecommons.org/licenses/by/ $4.0 /)$.
* Correspondence: luisa.quesada@uss.cl (L.Q.-R.); mario.simirgiotis@uach.cl (M.J.S.); Tel.: +56-632632811 (L.Q.-R.)

Abstract: Gaultheria pumila (Ericaceae) (known as Chaura or Mutilla) is a Chilean native small shrub that produces berry fruits consumed by local Mapuche people. In this study, the chemical fingerprinting and antioxidant, enzyme inhibition, and antiproliferative activities of the berries were investigated for the first time. Thirty-six metabolites were identified in the fruits by ultra-high performance liquid chromatography-photodiode array detection, hyphenated with Orbitrap mass spectrometry analysis (UHPLC-DAD-Orbitrap-MS). Metabolites, included anthocyanins, phenolic acids, flavonoids, iridoids, diterpenes, and fatty acids. Moderate inhibitory activities against acetylcholinesterase $(7.7 \pm 0.3 \mu \mathrm{g} / \mathrm{mL})$, butyrylcholinesterase $(34.5 \pm 0.5 \mu \mathrm{g} / \mathrm{mL})$, and tyrosinase $(3.3 \pm 0.2 \mu \mathrm{g} / \mathrm{mL})$ enzymes were found. Moreover, selected major compounds were subjected to docking assays in light of their experimental inhibition. Results indicated that hydrogen bonding, $\pi-\pi$ interaction, and a salt bridge interaction contributed significantly. Gaultheria pumila berries showed a total phenolic content of $189.2 \pm 0.2 \mathrm{mg}$ of gallic acid equivalents $/ \mathrm{g}$, total flavonoid content of $51.8 \pm 0.1 \mathrm{mg}$ quercetin equivalents $/ \mathrm{g}$, and total anthocyanin content of $47.3 \pm 0.2 \mathrm{mg}$ of cianydin3-glucoside equivalents/g. Antioxidant activity was assessed using DPPH (92.8 $\pm 0.1 \mu \mathrm{g} / \mathrm{mL})$, FRAP $(134.1 \pm 0.1 \mu \mathrm{mol}$ Trolox equivalents/g), and ORAC (4251.6 $\pm 16.9 \mu \mathrm{mol}$ Trolox equivalents/g) assays. Conversely, Gaultheria pumila showed a scarce antiproliferative potential against several solid human cancer cells. Our findings suggest that Gaultheria pumila berries have several bioactive metabolites with inhibitory effects against acetylcholinesterase, butyrylcholinesterase, and tyrosinase, and have the potential for use in food supplements.

Keywords: gaultheria; phenolics; enzyme inhibition; native berries; antioxidant

\section{Introduction}

The human consumption of native berries has been increasing worldwide in part due to their potential impact on health promotion and disease prevention. Fruit berries from a variety of species have been associated with a reduction in the risk of cardiovascular, neurodegenerative, and inflammatory diseases, as well as potential benefits against some forms of cancer [1]. The effects against reactive oxygen species (ROS) have been described 
as the main antioxidant protective mechanism [2]. Chile possesses a high biodiversity of native berries, which are mainly found in the central-southern region of the country and include different genuses such as Aristotelia, Fragaria, Berberis, Ugni, and Gaultheria, among others. The phytochemical and biological activities of plants belonging to those genuses have been reported previously [3].

The Gaultheria genus (Ericaceae) includes approximately 135 species, many of which have been used in traditional medicine to treat several diseases [4]. Some of their chemical constituents and pharmacological properties have been extensively investigated [5]. Antioxidant, antibacterial, anti-inflammatory, anticancer, and enzyme inhibitory properties have been reported in the scientific literature [6-9]. In Chile, the genus Gaultheria is distributed from the central region (Región Metropolitana) to the extreme south (Región de Magallanes), and twelve species have been formally registered including G. angustifolia, G. antarctica, G. cespitosa, G. insana, G. mucronata, G. nubigena, G. phyllireifolia, G. poeppigii, G. tenuifolia, G. renjifoana, G. racemulosa, and G. pumila [10]. Some of these plants are edible species (G. tenuifolia, G. phillyreifolia, G. poeppigii, G. mucronata, and G. pumila).

Anthocyanins and iridoids with important antioxidant activities have been isolated from the native berries of G. phillyreifolia and G. poeppigii [11]. The quantitative and qualitative profiles of phenolic compounds from different colored genotypes of G. poeppigii berries and their antioxidants activities have been evaluated [12]. Anthocyanins, proanthocyanidins, phenylpropanoids, iridoids, and flavonols have been isolated from G. tenuifolia berries [13]. The anthocyanin profiles, total anthocyanin content, and antioxidant activities from G. mucronata and G. antarctica have also been described [14], as well as the flavonols and hydroxycinnamic acid profiles [15]. In addition, morphometric analysis and the chemical characterization (total anthocyanin content and pectin) of red, pink, and white G. pumila berries have been investigated [16].

Gaultheria pumila is a native small bush $(2-3 \mathrm{~cm}$ tall) that produces a tasty, aromatic, and flavored fruit popularly known as "Chaura" or "Mutilla" and is consumed by local Mapuche communities (Figure 1).
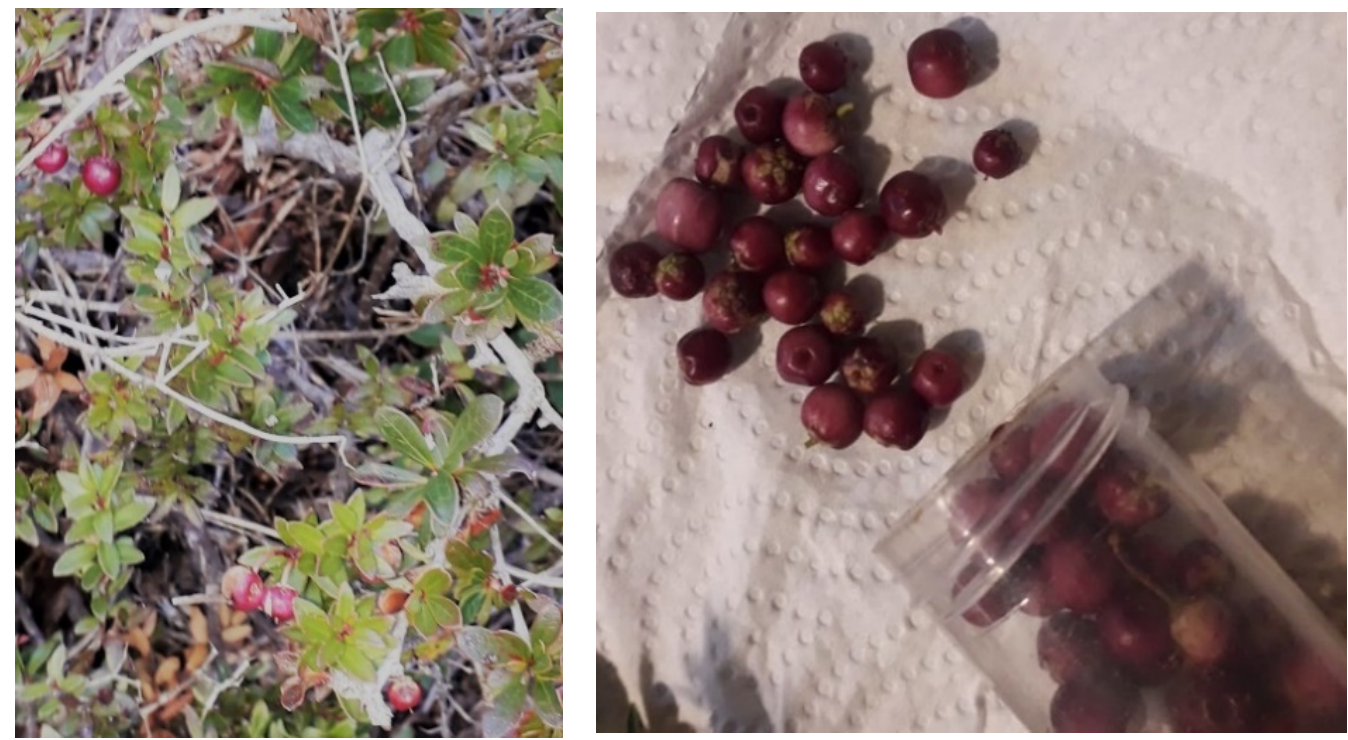

Figure 1. Gaultheria pumila (Ericaceae) shrub in Parque Nacional Conguillío (left) and Gaultheria pumila berries (right).

To date, no chemical fingerprinting of the metabolites from G. pumila berries have been investigated. To the best of our knowledge, there are no scientific reports concerning to the antiproliferative and enzyme inhibition potential. Ultra-high-resolution chromatography (UHPLC) coupled to mass spectrometry (MS) is a fast and modern technique that serves to provide information and compare the chemical profile of different metabolites that are 
naturally produced by plants $[17,18]$. Our group recently investigated the fingerprinting of Chilean native plants as well as their antioxidant and enzyme inhibitory properties $[19,20]$. In the present work, we report for the first time the chemical fingerprinting of G. pumila berries by UHPLC-MS analysis and the enzyme inhibition (against acetylcholinesterase, butyrylcholinesterase, and tyrosinase), as well as the antioxidant and antiproliferative activities.

\section{Materials and Methods}

\subsection{Chemicals}

Ultra-pure water $(<5 \mu \mathrm{g} / \mathrm{L}$ TOC) was obtained from the water purification systems Arium 126 61316-RO, in addition to an Arium 611 UV unit (Sartorius, Goettingen, Germany). Methanol (HPLC grade) and formic acid (MS grade) were purchased from J. T. Baker (Phillipsburg, NJ, USA). Commercial Folin-Ciocalteu (FC) reagent, 2,2-diphenyl-1-picrylhydrazyl (DPPH), ferric chloride hexahydrate, 2,4,6-tris(2-pyridyl)-s-triazine, trolox, quercetin, gallic acid, Amberlite ${ }^{\circledR}$ resin (XAD4), dimethyl sulfoxide (DMSO), acetylcholinesterase (AChE), butyrylcholinesterase (BChE), phosphate buffer, LDOPA, tyrosinase, kojic acid, trichloroacetic acid (Merck, Darmstadt, Germany), fetal calf serum (FCS, Gibco, Grand Island, NY, USA), L-glutamine (Merck, Darmstadt, Germany), penicillin G (Sigma, St. Louis, MO, USA), streptomycin (Sigma, St. Louis, MO, USA), sulforhodamine B (SRB, Sigma, St. Louis, MO, USA), and HPLC standards (cyandin-3-O-glucoside, delphinidin-3-O-galactoside, cyanidin-3-O-galactoside, cyanidin-3-O-arabinoside, and quercetin-3-O-arabinoside) with purity higher than $95 \%$ by HPLC were purchased from Sigma Aldrich Chem. Co. (St, Louis, MO, USA) or Extrasynthèse (Genay, France).

\subsection{Plant Material}

G. pumila (one sample, ripe fruits, purple morphotype, and sweet flavor) was collected by hand from the National Park Conguillío (Mirador de los Cóndores), Región de La Araucanía, Chile, in October 2019 ( $38^{\circ} 43^{\prime} 16.0^{\prime \prime}$ S, 71 $\left.33^{\circ} 41.5^{\prime \prime} \mathrm{W}\right)$. The sample was authenticated by the botanist Jorge Macaya from the University of Chile, Santiago, Chile. The sample was washed with distilled water and kept in an ultra-freezer at a desired temperature $\left(-95^{\circ} \mathrm{C}\right)$. A voucher specimen (voucher number GP-102019) was deposited in the Laboratory of Natural Products of the Universidad Austral de Chile (Chile).

\subsection{Extraction Procedures}

G. pumila (10 g) fruits were grounded using an electric processor (Ursus Trotter, UTPETRUS320) and extracted three times with a $100 \mathrm{~mL}$ mixture of MeOH:formic acid (98:2, $v / v$ ) using an ultrasonic water bath (UC-60A Biobase, Guanzhou, China) for $30 \mathrm{~min}$ in the dark. The resulting extract was then filtered and evaporated under reduced pressure at $36{ }^{\circ} \mathrm{C}$ to obtain $998 \mathrm{mg}$ of a gummy residue extract. A column filled with Amberlite ${ }^{\circledR}$ resin (XAD4, $200 \mathrm{~g}$ ) was used to achieve the flavonoid enriched extract. The extract was suspended in water $(20 \mathrm{~mL})$, added to the column $(200 \mathrm{~g})$, and washed several times with deionized water ( $100 \mathrm{~mL}, 3$ times); then, the compounds were desorbed with $\mathrm{MeOH}$ :formic acid $(98: 2, v / v, 100 \mathrm{~mL})$ and the solution was evaporated under reduced pressure at $36^{\circ} \mathrm{C}$ to give $479.23 \mathrm{mg}(4.79 \%)$. This procedure was previously used for other edible berries [21].

\subsection{UHPLC-DAD-MS Instrument}

A UHPLC-high-resolution MS machine (Thermo Dionex Ultimate 3000 system with DAD detector controlled by Chromeleon 7.2 software hyphenated with a Thermo QExactive MS focus) was used to analyze the phenolic compounds in the extract. For the analysis, $5 \mathrm{mg}$ of the enriched extract were dissolved in $2 \mathrm{~mL}$ of methanol, filtered through a $200-\mu \mathrm{m}$ polytetrafluoroethylene (PTFE) filter, and $10 \mu \mathrm{L}$ were injected into the instrument [22]. 


\subsection{LC Parameters and MS Parameters}

Liquid chromatography was performed using a UHPLC C18 column (Acclaim, $150 \times 4.6 \mathrm{~mm}$ ID, $2.5 \mu \mathrm{m}$; Thermo Fisher Scientific, Bremen, Germany) operated at $25^{\circ} \mathrm{C}$. The detection wavelengths were $280,254,330$, and $354 \mathrm{~nm}$, and photodiode array detectors were set from $200 \mathrm{~nm}$ to $800 \mathrm{~nm}$. Mobile phases were $1 \%$ formic aqueous solution (A) and acetonitrile $1 \%$ formic acid (B). The gradient program started at $5 \% \mathrm{~B}$ at time zero; was maintained at $5 \%$ B for $5 \mathrm{~min}$; went to $30 \%$ B for $10 \mathrm{~min}$; was maintained at $30 \%$ B for $15 \mathrm{~min}$; went to $70 \%$ B for $5 \mathrm{~min}$; was maintained at $70 \%$ B for $10 \mathrm{~min}$; and was finally returned to the initial conditions within $10 \mathrm{~min}$ and $12 \mathrm{~min}$ for column equilibration prior to each injection. The flow rate was $1.00 \mathrm{~mL} / \mathrm{min}$ and the injection volume was $10 \mu \mathrm{L}$. The standards and lyophilized decoction dissolved in methanol were kept at $10{ }^{\circ} \mathrm{C}$ during its storage in the autosampler. The HESI II and Orbitrap spectrometer parameters were optimized as previously reported [23]. Briefly, the parameters are as follows: sheath gas flow rate, 75 units; auxiliary gas unit flow rate, 20; capillary temperature, $400{ }^{\circ} \mathrm{C}$; auxiliary gas heater temperature, $500{ }^{\circ} \mathrm{C}$; spray voltage, $2500 \mathrm{~V}$ (for ESI-); and S lens, RF level 30. Full scan data in positive and negative modes were acquired at a resolving power of 70,000 FWHM at $m / z 200$. Themass scan range was between of 100-1000 $\mathrm{m} / z$; automatic gain control (AGC) was set at $3 \times 10^{6}$ and the injection time was set to $200 \mathrm{~ms}$. The chromatographic system was coupled to MS with a source II heated electro-nebulization ionization probe (HESI II). The nitrogen gas carrier (purity $>99.999 \%$ ) was obtained from a Genius NM32LA (Peak Scientific, Billerica, MA, USA) generator and used as a collision and damping gas. Mass calibration for Orbitrap was performed once a day in both negative and positive modes to ensure working mass $5 \mathrm{ppm}$ of accuracy. For the positive mode, a mixture of caffeine $(1 \mathrm{mg} / \mathrm{mL}, 20 \mu \mathrm{L})$ and N-butylamine $(1 \mathrm{mg} / \mathrm{mL}, 100 \mu \mathrm{L})$ was used, while a mixture of sodium dodecyl sulfate $(1 \mathrm{mg} / \mathrm{mL}, 100 \mu \mathrm{L})$ and taurocholic acid sodium salt $(1 \mathrm{mg} / \mathrm{mL}, 100 \mu \mathrm{L})$ (Sigma-Aldrich, Darmstadt, Germany) was used for the negative mode. In addition, Ultramark 1621 (Alpha Aezar, Stevensville, MI, USA) was used as the reference compound $(1 \mathrm{mg} / \mathrm{mL}, 100 \mu \mathrm{L})$. These compounds were dissolved in a mixture of acetic acid $(100 \mu \mathrm{L})$, acetonitrile $(5 \mathrm{~mL})$, water: methanol (1:1) $(5 \mathrm{~mL})$ (Merck, Santiago, Chile), and $20 \mu \mathrm{L}$ of the mixture were infused using a Chemyx Fusion $100 \mu \mathrm{L}$ syringe pump (Thermo Fisher Scientific, Bremen, Germany. The tentative identification of the metabolites was carried out using the analysis of the full scan mass spectra, retention index, base peaks chromatograms, fragmentation pattern, and database of MassBank of North America (MoNA). In addition, representative compounds were identified using the commercial standards presented in Section 3.1.

\subsection{Total Phenolic (TP), Total Flavonoid (TF), and Total Anthocyanins (TA) Content}

The total phenolic (TP) and total flavonoid (TF) content of G. pumila berries was measured using the Folin-Ciocalteu and the $\mathrm{AlCl}_{3}$ method employing a Synergy HTX microplate reader (Biotek, Winoosky, VT, USA) as reported previously [24,25]. Results for $\mathrm{TP}$ are expressed as the mg gallic acid equivalent per $\mathrm{g}$ of dry plant and the results for TF are expressed as the mg quercetin equivalent per g of dry plant. Total anthocyanin (TA) content was carried out by the $\mathrm{pH}$ differential method [26]. Buffers at $\mathrm{pH} 1.0$ and 4.5 were used and the absorbance was detected at $510 \mathrm{~nm}$ and $700 \mathrm{~nm}$, respectively. Results were expressed as the mg cyanidin-3-glucoside equivalents/g extract [26]. The experiments were performed in triplicates and the values are reported as the mean $\pm \mathrm{SD}$.

\subsection{Antioxidant Activity}

\subsubsection{DPPH Scavenging Activity}

Using a Synergy HTX microplate reader, the potential bleaching of the radical DPPH was determined using $150 \mu \mathrm{L}$ of DPPH solution $(0.075 \mathrm{mM})$ and $50 \mu \mathrm{L}$ of extract or the standard gallic acid (curve from 10-250 $\mu \mathrm{g} / \mathrm{mL}$ ). The determinations were made in triplicates by monitoring the disappearance of DPPH at $515 \mathrm{~nm}$ after $30 \mathrm{~min}$ of reaction [22,23]. 
The results are expressed as $\mathrm{IC}_{50}$ in $\mu \mathrm{g}$ of the extract or standard per $\mathrm{mL}$. The values are reported as the mean $\pm \mathrm{SD}$.

\subsubsection{Ferric-Reducing Antioxidant Power Assay (FRAP)}

The FRAP assay was performed as previously described [19]. Quantification was performed using a standard curve of the antioxidant Trolox. Then, the measurement was performed using a volume of $10 \mu \mathrm{L}$ of Trolox and $290 \mu \mathrm{L}$ of extract in a well of the microplate and absorbance was measured at $593 \mathrm{~nm}$ after $5 \mathrm{~min}$. Trolox was used as the standard (curve made from $1-100 \mu \mathrm{g} / \mathrm{mL}$ ). The results were expressed in $\mu \mathrm{mol}$ of the Trolox equivalent per $g$ of dry fruit. The experiments were performed in triplicates and the values are expressed as the mean $\pm \mathrm{SD}$.

\subsubsection{Oxygen Radical Absorbance Capacity (ORAC) Assay}

The ORAC assay was performed as previously described [27]. Quantification was performed using a standard curve of the antioxidant Trolox (curve from 10-100 $\mu \mathrm{M}$ ). The results were obtained by the quadratic regression equation (Trolox/samples vs. fluorescence decay curves) and expressed in $\mu \mathrm{mol}$ of the Trolox equivalents per $g$ of dry plant. The experiments were performed in triplicates and the values are reported as the mean \pm SD.

\subsection{Determination of Cholinesterase Inhibition}

Inhibition of AChE activity was determined according to the Ellman method as previously reported [23]. Briefly, DTNB was dissolved in buffer Tris- $\mathrm{HCl}$ at $\mathrm{pH} 8.0$ containing $0.1 \mathrm{M} \mathrm{NaCl}$ and $0.02 \mathrm{M} \mathrm{MgCl}_{2}$. Then, a filtered sample solution dissolved in deionized water $(50 \mu \mathrm{L}$, the final concentration of the plate was ranging from 0.05 to $25 \mu \mathrm{g} / \mathrm{mL})$ was mixed with $125 \mu \mathrm{L}$ of 5-dithio-bis (2-nitrobenzoic) acid (DTNB), acetylcholinesterase (AChE), or butyrylcholinesterase (BuChE) solution $(25 \mu \mathrm{L})$ dissolved in Tris-HCl buffer at pH 8.0 in a 96-well microplate and was incubated for $15 \mathrm{~min}$ at $25^{\circ} \mathrm{C}$. Initiation of the reaction was performed by the addition of acetyl-thiocholine iodide (ATCI) or butyrylthiocholine chloride (BTCl) $(25 \mu \mathrm{L})$. In addition, a blank was prepared by adding the solution sample to all reagents without the enzyme(s) (AChE or BuChE) solutions. The sample and blank absorbances were then read at $405 \mathrm{~nm}$ after $10 \mathrm{~min}$ of incubation at $25^{\circ} \mathrm{C}$. The absorbance of the sample was subtracted from that of the blank and the cholinesterase inhibitory capacity was expressed as $\mathrm{IC}_{50}(\mu \mathrm{g} / \mathrm{mL})$. A Synergy HTX Multi-Mode Microplate Reader (BioTek Instruments Inc., Foster City, CA, USA) was used. Three experiments were performed in triplicates in each case and the values are reported as the mean $\pm \mathrm{SD}$. Galanthamine was used as positive control.

\subsection{Tyrosinase Inhibition Assay}

Tyrosinase activity was assessed using the dopachrome method [28]. G. pumila berries $(20 \mu \mathrm{L}$ in EtOH) with $30 \mu \mathrm{L}$ of $\mathrm{pH} 6.8$ phosphate buffer $(0.067 \mathrm{M}, \mathrm{pH} 6.8), 40 \mu \mathrm{L}$ of the enzyme tyrosinase $(100 \mathrm{U} / \mathrm{mL})$ and $40 \mu \mathrm{L}$ of the substrate L-DOPA $(2.5 \mathrm{mM})$ were added to each well. The reaction was incubated for $15 \mathrm{~min}$ at $24^{\circ} \mathrm{C}$ and the absorbance was read at $492 \mathrm{~nm}$. The results were expressed as $\mathrm{IC}_{50}(\mu \mathrm{g} / \mathrm{mL})$, the final concentration of the plate ranged from 31.25 to $250 \mu \mathrm{g} / \mathrm{mL}$, and the experiments were performed in triplicate. The values are reported as mean $\pm \mathrm{SD}$. Kojic acid was used as positive control.

\subsection{Docking Studies}

Docking simulations were carried for selected major compounds shown in Figure S1 (Supplementary Materials) obtained from Gaultheria pumila berries extract. First, the geometries and partial charges of every compound were fully optimized using the DFT method with the standard basis set PBE0/6-311 + $\mathrm{g}^{*}[29,30]$ in Gaussian 09W software, version 9.0. Then, energetic minimizations and protonations or deprotonation (if applicable) were carried out using the LigPrep tool in Maestro Schrödinger suite v.11.8 (Schrödinger, LLC). Crystallographic enzyme structures of Torpedo Californica acetylcholinesterase (TcAChE; 
PDBID: 1DX6 code) [31], human butyrylcholinesterase (hBuChE; PDBID: 4BDS code) [32], and the Agaricus bisporus mushroom tyrosinase (tyrosinase; PDBID: 2Y9X code) [33] were downloaded from the Protein Data Bank RCSB PDB [34] (for full description, see Supplementary Material).

\subsection{Antiproliferative Activity}

For the antiproliferative activity, $100 \mu \mathrm{L}$ of cells with a density of 2500 (A549, HBL-100, HeLa, and SW1573) and 5000 (T-47D and WiDr) were added to each well. The plant extract was dissolved in DMSO at $100 \mathrm{mg} / \mathrm{mL}$ (400 times the desired maximum test concentration) and tested in triplicates at dilution ranges from $2.5 \mu \mathrm{g} / \mathrm{mL}$ to $250 \mu \mathrm{g} / \mathrm{mL}$. Furthermore, control cells were exposed in DMSO $(0.25 \% v / v$, negative control). After $24 \mathrm{~h}$, the extracts were incubated for $48 \mathrm{~h}$ and the cells were precipitated with $25 \mu \mathrm{L}$ of ice-cold TCA (50\% $w / v$ ), fixed for $60 \mathrm{~min}$ at $4{ }^{\circ} \mathrm{C}$ [35]. Finally, in each well, the optical density (OD) was measured at $530 \mathrm{~nm}$ and this was conducted with the Sulforhodamine B (SRB) assay and using the BioTeK Power Wave XS absorbance microplate reader. Values were corrected with the background OD of the wells containing the control. The antiproliferative activity of the extracts was expressed as the $50 \%$ reduction in cancer cell growth $\left(\mathrm{GI}_{50}\right)$ and total growth inhibition (TGI).

\subsection{Statistical Analysis}

All the experiments were repeated at least three times. The results were expressed as mean \pm standard deviation (SD) using GraphPad Prism 8. The comparison of results was performed using one-way analysis of variance (ANOVA), followed by Tukey's HSD (Honest Significant Difference) test $(p<0.01)$.

\section{Results and Discussion}

\subsection{UHPLC-MS Analysis of Gaultheria Pumila Extract}

The fingerprinting of the enriched extract of G. pumila berries was investigated by means of UHPLC-high-resolution MS and DAD analysis. The negative mode was used for the identification of phenolic compounds, while the positive mode was used for anthocyanins. Some of the metabolites identified are reported for the first time in this species. In total, 36 metabolites were detected and tentatively identified including anthocyanins, phenolic acids, flavonoids, iridoids, terpenes, and fatty acids (see Figures 2 and 3, Table 1, and Figure S1, Supplementary Material). A detailed analysis is depicted below.

\subsubsection{Anthocyanins}

Five anthocyanins with $\lambda$ max at $520 \mathrm{~nm}$ were detected in G. pumila berries using UHPLC-DAD-MS analysis in the positive mode (Figure 2). Peak 1a and 2a showed a common $\mathrm{MS}^{2}$ fragment, in agreement with delphinidin $\left(\mathrm{C}_{15} \mathrm{H}_{11} \mathrm{O}_{7}{ }^{+}\right)$at $\mathrm{m} / z=303.30396$ and $m / z=303.05667$. Peak 1 a was identified as delphinidin 3-O-arabinoside $\left(\mathrm{C}_{20} \mathrm{H}_{19} \mathrm{O}_{11}{ }^{+}\right)$ and peak $2 \mathrm{a}$ as delphinidin 3-O-galactoside $\left(\mathrm{C}_{21} \mathrm{H}_{21} \mathrm{O}_{12}{ }^{+}\right)$[21]. The mass spectra peak $3 \mathrm{a}$ and 4 a showed a diagnostic cyanidin $\mathrm{MS}^{2}$ ion at $m / z=287.06052$ and $m / z=280.06049$, and were identified as cyanidin-3-O-galactoside $\left(\mathrm{C}_{21} \mathrm{H}_{21} \mathrm{O}_{11}{ }^{+}\right)$and cyanidin-3-O-arabinoside $\left(\mathrm{C}_{20} \mathrm{H}_{19} \mathrm{O}_{10}{ }^{+}\right)$[21]. Peak 5a $(m / z=493.10559)$ with a daughter ion at $m / z=301.16412$, in agreement with peonidin, was identified as peonidin-3-O-galactoside $\left(\mathrm{C}_{22} \mathrm{H}_{23} \mathrm{O}_{11}{ }^{+}\right)$[21] . From Chilean Gaultheria compounds, 1a, 2a, 3a, and 4a were previously identified on G. phillyreifolia [11], G. poeppigii [11], and G. antartica [14], and compounds 3a and 4a in G. tenuifolia berries [13]. To the best of our knowledge, compound 5a is reported for the first time in G. pumila. In addition, from Chilean G. mucronata, some undetected anthocyanins such as cyanidin-3-lathyroside and cyanidin-dipentoside were also identified [14]. 


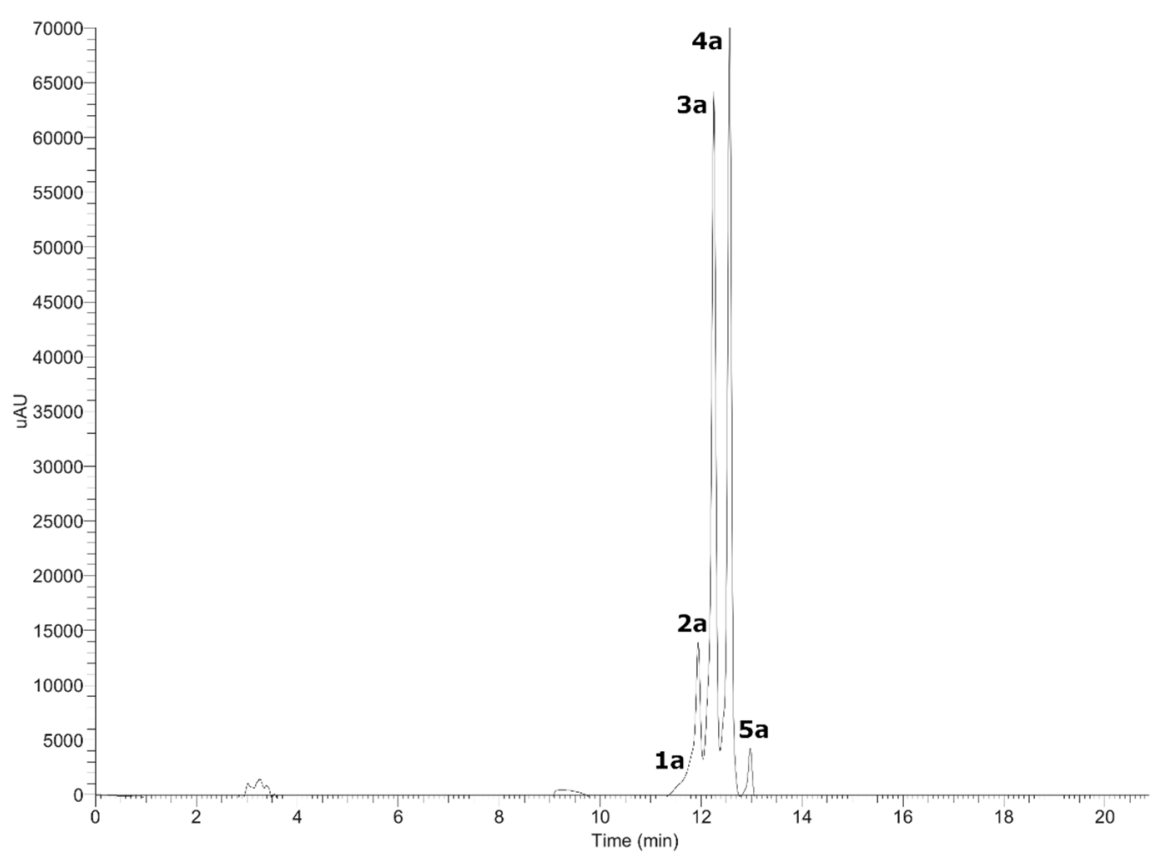

Figure 2. UHPLC-DAD chromatogram of anthocyanins from Gaultheria pumila at $520 \mathrm{~nm}$.

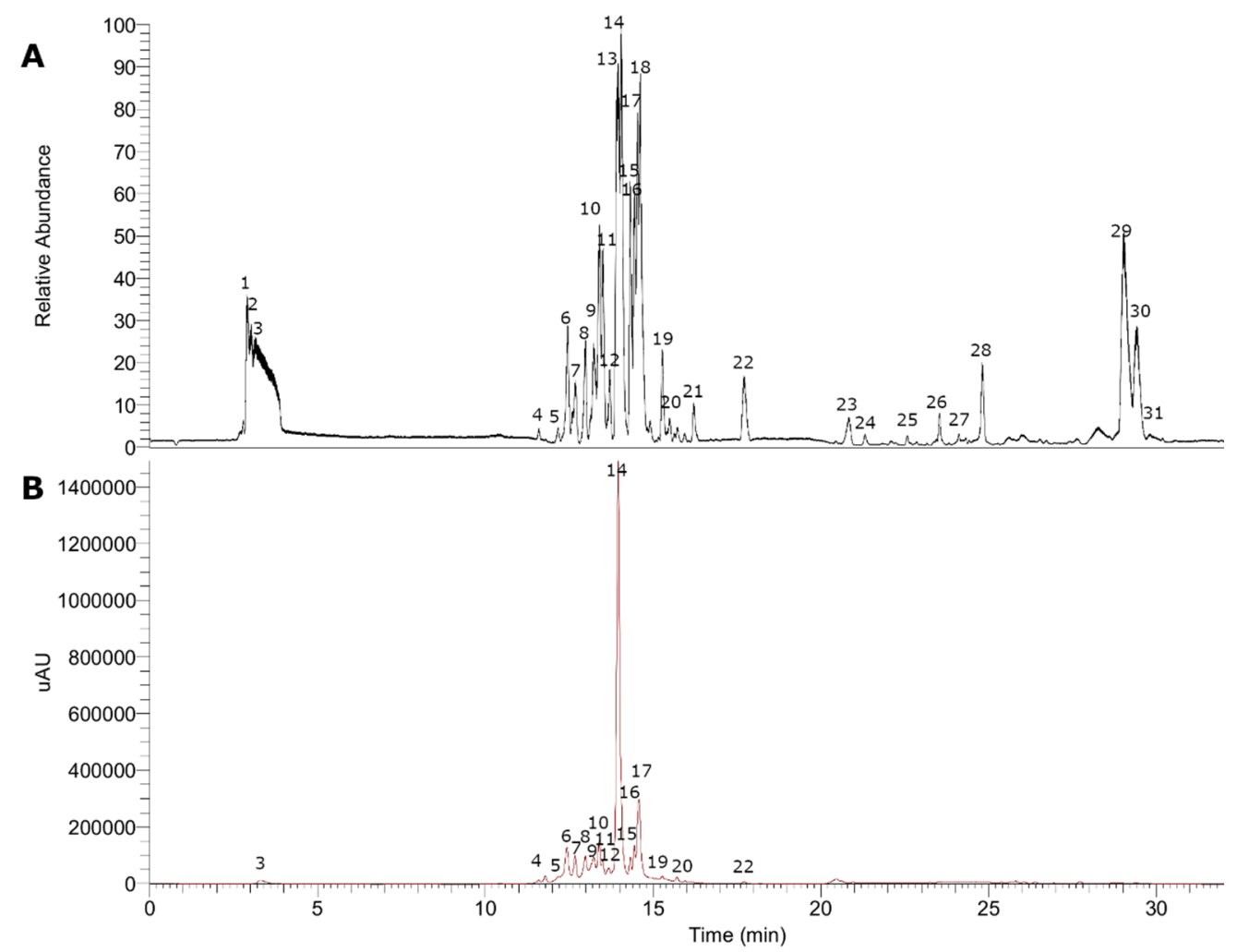

Figure 3. UHPLC chromatograms in the negative mode of Gaultheria pumila. (A) TIC chromatogram. (B) UV at $280 \mathrm{~nm}$. 
Table 1. Tentative identification of secondary metabolites from Gaultheria pumila fruits.

\begin{tabular}{|c|c|c|c|c|c|c|c|c|}
\hline Peak & RT & $\begin{array}{c}\lambda \operatorname{Max} \\
(\mathrm{nm})\end{array}$ & $\begin{array}{c}\text { Elemental Composition } \\
{[\mathbf{M}+\mathbf{H}]^{+}} \\
{[\mathbf{M}-\mathbf{H}]^{-}}\end{array}$ & $\begin{array}{l}\text { Measured } \\
\text { Mass } \\
(\mathrm{m} / \mathrm{z})\end{array}$ & $\begin{array}{c}\text { Theorical } \\
\text { Mass } \\
(m-z)\end{array}$ & $\begin{array}{l}\text { Accuracy } \\
(\mathrm{ppm})\end{array}$ & MS $^{\mathrm{n}}$ Ions & Tentative Identification \\
\hline $1 \mathrm{a}$ & 11.45 & $234-282-520$ & $\mathrm{C}_{20} \mathrm{H}_{19} \mathrm{O}_{11}^{+}$ & 435.10989 & 435.09219 & 40.685 & $\begin{array}{c}\text { 303.05676, 247.12254, 178.13483 } \\
155.15498,130.00858\end{array}$ & Delphinidin-3-O-arabinoside \\
\hline $2 a$ & 11.94 & $239-522$ & $\mathrm{C}_{21} \mathrm{H}_{21} \mathrm{O}_{12}^{+}$ & 465.12381 & 465.10275 & 45.144 & $\begin{array}{c}303.05667,247.12254,183.10243 \\
130.15967\end{array}$ & Delphinidin 3-O-galactoside * \\
\hline $3 a$ & 12.26 & $280-521$ & $\mathrm{C}_{21} \mathrm{H}_{21} \mathrm{O}_{11}^{+}$ & 449.12598 & 449.10784 & 40.394 & $\begin{array}{c}287.06052,247.12250,171.09984 \\
147.04466\end{array}$ & Cyanidin 3-O-galactoside * \\
\hline $5 a$ & 12.99 & $238-309-516$ & $\mathrm{C}_{22} \mathrm{H}_{23} \mathrm{O}_{11}^{+}$ & 463.10559 & 463.12349 & -38.648 & $301.16412,225.81639,171.09319$ & Peonidin-3-O-glucoside \\
\hline 1 & 2.94 & 232 & $\mathrm{C}_{18} \mathrm{H}_{17} \mathrm{O}_{9}^{-}$ & 377.08575 & 377.08781 & -2.542 & $279.19812,218.78490,162.83897$ & Vaccihein A \\
\hline 2 & 3.06 & 232 & $\mathrm{C}_{16} \mathrm{H}_{23} \mathrm{O}_{12}-$ & 407.11966 & 407.11950 & 3.089 & $295.51428,156.00233,119.60213$ & Unedide \\
\hline 3 & 3.38 & 256 & $\mathrm{C}_{19} \mathrm{H}_{11} \mathrm{O}_{6}^{-}$ & 335.05420 & 335.05611 & -2.431 & $268.80099,215.03267,160.84152$ & Pongapin \\
\hline 4 & 11.58 & $234-297$ & $\mathrm{C}_{16} \mathrm{H}_{17} \mathrm{O}_{9}^{-}$ & 353.08820 & 353.08781 & 4.224 & $\begin{array}{c}314.02936, \begin{array}{c}191.05566,135.04482 \\
109.02880\end{array}\end{array}$ & $\begin{array}{c}\text { Caffeoylquinic acid } \\
\text { derivative }\end{array}$ \\
\hline 5 & 12.17 & $236-282$ & $\mathrm{C}_{12} \mathrm{H}_{13} \mathrm{O}_{8}^{-}$ & 285.06189 & 285.06159 & 4.898 & $219.44096,167.07101,108.02096$ & Uralenneoside \\
\hline 6 & 12.47 & $236-299$ & $\mathrm{C}_{16} \mathrm{H}_{17} \mathrm{O}_{9}^{-}$ & 353.08804 & 353.08781 & 3.771 & $707.18433,191.05592$ & Chlorogenic acid \\
\hline 7 & 12.67 & $236-282-517$ & $\mathrm{C}_{20} \mathrm{H}_{17} \mathrm{O}_{10}-$ & 417.08307 & 417.08272 & 3.469 & $163.03966,128.04340,119.04950$ & Coumaric acid glucoside \\
\hline 9 & 13.25 & $237-323$ & $\mathrm{C}_{16} \mathrm{H}_{15} \mathrm{O}_{8}^{-}$ & 335.07755 & 335.07724 & 4.196 & $213.96364,179.03458,135.04459$ & 5-O-Caffeoylshikimic acid \\
\hline 10 & 13.39 & $238-326$ & $\mathrm{C}_{25} \mathrm{H}_{27} \mathrm{O}_{14}^{-}$ & 551.14050 & 551.14063 & 1.757 & $\begin{array}{l}179.03439 \\
135.04460\end{array}$ & Caffeic acid derivative \\
\hline 11 & 13.50 & $254-354$ & $\mathrm{C}_{21} \mathrm{H}_{19} \mathrm{O}_{13}^{-}$ & 479.08319 & 479.08311 & 2.448 & $\begin{array}{c}317.09708,289.08298,213.96367 \\
115.91998\end{array}$ & Myricetin-O-hexoside \\
\hline 12 & 13.70 & 238 & $\mathrm{C}_{20} \mathrm{H}_{17} \mathrm{O}_{12}{ }^{-}$ & 449.07294 & 449.07255 & 3.313 & $319.04620,183.02954,134.89410$ & Methyl gallate derivative \\
\hline 13 & 13.96 & $241-304$ & $\mathrm{C}_{25} \mathrm{H}_{27} \mathrm{O}_{13}^{-}$ & 535.14545 & 535.14571 & 1.556 & $357.11948,163.03975,119.04951$ & $\begin{array}{l}p \text {-coumaroyl monotropein } \\
\text { isomer }\end{array}$ \\
\hline 14 & 14.05 & $255-352$ & $\mathrm{C}_{21} \mathrm{H}_{19} \mathrm{O}_{12}{ }^{-}$ & 463.08838 & 463.08820 & 2.759 & $385.11417,281.06665,163.03955$ & Myricetin-O-rhamnoside \\
\hline 15 & 14.34 & $243-351$ & $\mathrm{C}_{20} \mathrm{H}_{17} \mathrm{O}_{11}^{-}$ & 433.07782 & 433.07763 & 2.961 & $\begin{array}{c}\text { 300.02753, 279.05096, 151.00316, } \\
138.07101,107.01299\end{array}$ & Quercetin 3-O-ribose \\
\hline 16 & 14.41 & $255-351$ & $\mathrm{C}_{20} \mathrm{H}_{17} \mathrm{O}_{11}^{-}$ & 433.07776 & 433.07763 & 2.822 & $\begin{array}{c}300.02744,151.03909134 .89404 \\
115.91995\end{array}$ & Quercetin 3-O-arabinoside * \\
\hline 17 & 14.53 & $255-347$ & $\mathrm{C}_{20} \mathrm{H}_{17} \mathrm{O}_{11}^{-}$ & 433.07773 & 433.07763 & 2.753 & $\begin{array}{c}301.03571,263.05963,151.00317 \\
115.92000\end{array}$ & Quercetin 3-O-xyloside \\
\hline
\end{tabular}


Table 1. Cont.

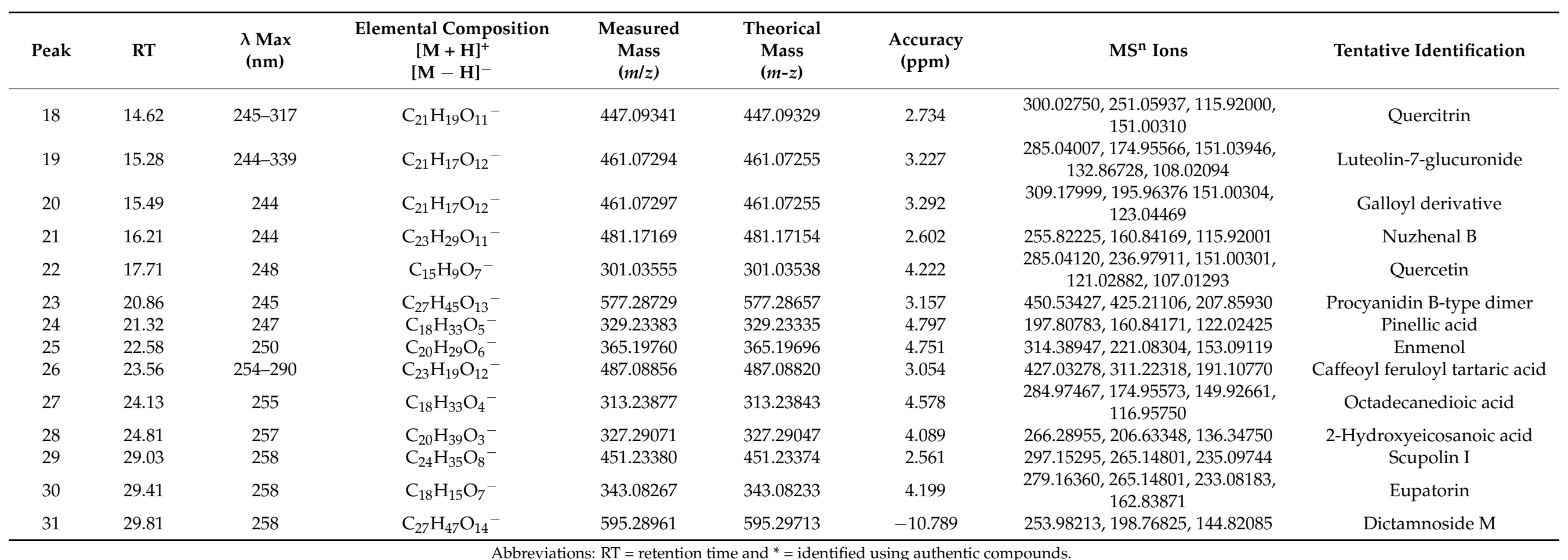




\subsubsection{Flavonoids and Derivatives}

Peak 3 with a $[\mathrm{M}-\mathrm{H}]^{-}$ion at $m / z=335.05420$ was identified as the apoptotic furanoflavonoid pongapin $\left(\mathrm{C}_{19} \mathrm{H}_{11} \mathrm{O}_{6}{ }^{-}\right)$[36]. Peak 8 was identified as isoschaftoside [37]. Peak 11 and 14 with flavonol absorbance $\left(\lambda_{\max }\right.$ at $\left.254,354 \mathrm{~nm}\right)$ and with anions at 479.08319 and 463.08838 were identified as myricetin-O-hexoside and myricetin-O-rhamnoside, previously identified from G. phillyreifolia [11], G. poeppigii [11] and G. antartica [14] berries. Peak 15, 16, and 17 were identified as quercetin derivatives $\left(\lambda_{\max }\right.$ at $\left.351 \mathrm{~nm}\right)$ : quercetin 3-O-ribose $(m / z=433.07782)$, quercetin 3-O-arabinoside $(m / z=433.07776)$, and quercetin 3-O-xylose $(m / z=433.07773)$. Peak $15,16,17$ showed common fragments at $m / z=301$ $\left(\mathrm{C}_{15} \mathrm{H}_{9} \mathrm{O}_{7}^{-}\right)$formed by the loss of pentose moiety. In addition, fragments at $\mathrm{m} / \mathrm{z}=151$ $\left(\mathrm{C}_{7} \mathrm{H}_{3} \mathrm{O}_{4}{ }^{-}\right)$and $m / z=107\left(\mathrm{C}_{6} \mathrm{H}_{3} \mathrm{O}_{2}{ }^{-}\right)$formed by the retro Diels-Alder reaction of quercetin moiety were also identified. Peak 18 with a $m / z=447.09341$ was identified as quercitrin $\left(\mathrm{C}_{21} \mathrm{H}_{19} \mathrm{O}_{11}{ }^{-}\right)$and showed a diagnostic fragment at $m / z=300.0275$ due the loss of hexoside moiety, while peak 22 with a $[\mathrm{M}-\mathrm{H}]^{-}$ion at $m / z=301.03561$ was identified as quercetin aglycone [38]. Quercetin derivatives have been previously reported from G. phillyreifolia [11], G. poeppigii [11], G. mucronata [14], and G. antartica [14]. Peak 19 with a [M-H] ${ }^{-}$ ion at $m / z=461.07294$ was identified as luteolin 7-glucuronide according to characterized fragmentation. From Chinese G. trichocada, one luteolin derivative (luteolin-7-O- $\beta$-Dglucoside) was isolated and characterized [39]. Peak 23 was identified as procyanidin B-type dimer $\left(\mathrm{C}_{27} \mathrm{H}_{45} \mathrm{O}_{13}{ }^{-}\right)$, previously detected on Chilean Gaultheria [11]. Peak 30 with a $m / z=343.08267$ was identified as eupatorin $\left(\mathrm{C}_{18} \mathrm{H}_{15} \mathrm{O}_{7}{ }^{-}\right)$, previously identified from the fruits of Vitex agnus-castus [40].

\subsubsection{Phenolic Acids}

Peak 1 with a $m / z=377.08575$ was identified as vaccihein A, previously isolated from the blueberry Vaccinium ashei [41]. Peak 4 showed a [M-H] ${ }^{-}$ion at $m / z=377.08575$ with a daughter ion at $m / z=191.05566$ (quinic acid portion) and $m / z=135.04482$ (formed by the decarboxylation of the caffeic acid portion) in agreements with a caffeoylquinic acid derivative $\left(\mathrm{C}_{1617} \mathrm{O}_{9}{ }^{-}\right)$[42], also described on G. phillyreifolia, G. poeppigii [11], and G. mucronata [15]. Peak 5 was identified as the 1-O-protocatechuyl-beta-xylose: uralenneoside $\left(\mathrm{C}_{12} \mathrm{H}_{13} \mathrm{O}_{8}{ }^{-}\right)$[43]. Peak $6(\lambda \max 325 \mathrm{~nm})$ showed a deprotonated molecule at $m / z=353.08804$, an adduct ion at $m / z=707.18433\left(\left[2 \mathrm{M}^{-} \mathrm{H}\right]^{-}\right)$, and daughter ion at $m / z=191.05592$ (quinic acid), and thus was tentatively identified as chlorogenic acid $\left(\mathrm{C}_{16} \mathrm{H}_{17} \mathrm{O}_{9}{ }^{-}\right)$, previously isolated from G. trichocada [39]. Peak 7 showed a [M-H] $]^{-}$ion at $m / z=417.08307$ with a daughter ion at $m / z=163.03966$ (loss of glucose) and $m / z=119.04950$ (decarboxylated coumaric acid), and was identified tentatively as coumaric acid glucoside [44,45]. Peak 9 with a $m / z=335.07755$ was identified as 5-O-Caffeoylshikimic acid, also reported in G. phillyreifolia and G. poeppigii [11]. Peak 10 with a deprotonated molecule at $m / z=551.14050$ and with MS $^{2}$ fragment at $m / z=179.03439$ (caffeic acid) was assigned as a caffeic acid derivative $\left(\mathrm{C}_{25} \mathrm{H}_{27} \mathrm{O}_{14}{ }^{-}\right)$[46]. Peak 12 with a pseudo-molecular ion at $m / z=449.07294\left(\mathrm{C}_{20} \mathrm{H}_{17} \mathrm{O}_{12}{ }^{-}\right)$was identified as a methyl gallate derivative. From Rhododendron ambiguum (Ericaceae) fruits, methyl gallate glucosides were identified [47]. Peak 20 was identified as a galloyl derivative $(m / z=461.07297)$ [9]. In the $\mathrm{MS}^{2}$ spectrum, the precursor ion showed a fragment at $m / z=309.17999$, formed by the loss of galloyl moiety at $m / z=151.00304\left(\mathrm{C}_{7} \mathrm{H}_{3} \mathrm{O}_{4}{ }^{-}\right)$. Peak 26 with a deprotonated molecule at $m / z=487.08856$ was identified as caffeoyl feruloyl tartaric acid $\left(\mathrm{C}_{23} \mathrm{H}_{19} \mathrm{O}_{12}{ }^{-}\right)$[48].

\subsubsection{Fatty Acids}

Peak 24 with a $m / z=329.23383$ was identified as pinellic acid $\left(\mathrm{C}_{18} \mathrm{H}_{33} \mathrm{O}_{5}{ }^{-}\right)$[49], peak 27 as octadecanedioic acid [50], and peak 28 with a deprotonated molecular ion at $m / z 327.29071$ as 2-hydroxyeicosanoic acid $\left(\mathrm{C}_{20} \mathrm{H}_{39} \mathrm{O}_{3}{ }^{-}\right)$[51]. Some fatty acids (stearic acid and palmitic acid) were identified and isolated previously from Gaultheria itoana [52]. 


\subsubsection{Terpenoids}

Iridoids are monoterpenoids previously described in Gaultheria species. Coumaroyl iridoids were predominantly derived from G. poeppigii berries and G. phillyreifolia [11,12], and the secoiridoid Swertiamari and methoxygeniposidic acid, among others, were derived from G. tenuifolia [13]. Three iridoids were tentatively identified in G. pumila. Peak 2 with a deprotonated molecule at $m / z 407.11966\left(\mathrm{C}_{16} \mathrm{H}_{23} \mathrm{O}_{12}{ }^{-}\right)$was identified as the iridoid glucoside unedide (6,7-dihydro-6 $\beta$-hydroxymonotropein), also found in the Ericaceae family [53]. Peak 13 with a $m / z=535.14545$ showed a characteristic fragment at $m / z=163.03975$ (coumaroyl unit) and was identified as the iridoid $p$-coumaroyl monotropein isomer $\left(\mathrm{C}_{25} \mathrm{H}_{27} \mathrm{O}_{13}{ }^{-}\right)$, previously reported in G. phillyreifolia and G. poeppigii [11]. Peak 21 was identified as the secoiridoid nuzhenal $\mathrm{B}\left(\mathrm{C}_{23} \mathrm{H}_{29} \mathrm{O}_{11}{ }^{-}\right)$, reported in the fruits of Ligustrum lucidum [54]. In addition, peak 25 with a $m / z=365.19760$ was identified as the diterpenoid

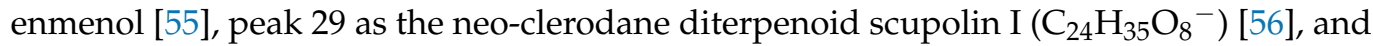
peak 31 as the sesquiterpenoid dictamnoside M [57].

\subsection{Total Phenolic, Flavonoid, and Anthocyanin Content, and Antioxidant Activity}

Gaultheria pumila extract was assessed in vitro for total phenolic (TP), flavonoid (TF), and anthocyanin (TA) content, and antioxidant activity. The results are summarized in Table 2. To determine the antioxidant activity of a sample, it is important to combine several antioxidant experiments (e.g., DPPH, FRAP, and ORAC, among others) as these provide useful information on the interaction between radicals and samples, and also provide complementary information on reactive oxygen species (ROS) $[23,58]$. The results of TP, TF, TA, and the antioxidant activity were compared with previously published data related to G. phillyreifolia, G. poeppigii [11], G. shallon [59], and G. erecta [60] berries. From G. pumila berries, 36 metabolites were identified, some of which are flavonoids and derivatives, phenolic acids, iridoids, terpenes, and fatty acids. The results observed for TP and TF of G. pumila were $189.2 \pm 0.2 \mathrm{mg}$ gallic acid equivalent per $\mathrm{g}$ of extract and $51.8 \pm 0.1 \mathrm{mg}$ quercetin equivalent per g of extract, respectively. From purple fruits of G. phillyreifolia and G. poeppigii, the highest values for TP were $290.3 \mathrm{mg}$ gallic acid equivalent per $\mathrm{g}$ and $184.4 \mathrm{mg}$ quercetin equivalent per $\mathrm{g}$ for TF [11]. The Colombian G. erecta TP value was $881.3 \mathrm{mg}$ gallic acid equivalent per $\mathrm{g}$ [60]. TA value for G. pumila was $47.3 \pm 0.2 \mathrm{mg}$ cyanidin-3-glucoside per g of extract. From Chilean G. phillyreifolia and G. poeppigii, reported values ranged from 8 to $87 \mathrm{mg}$ cyanidin-3-glucoside equivalent per $\mathrm{g}$ [11]. In addition, previous studies from G. pumila berries collected from different locations showed similar results with our samples (59.42 mg cyanidin-3-glucoside per g) [16]. G. pumila berries showed better antioxidant activity in the ORAC $(4251.6 \pm 16.9 \mu \mathrm{M}$ Trolox equivalents per $100 \mathrm{~g}$ of the dry plant) and $\mathrm{DPPH}(92.8 \pm 0.1 \mu \mathrm{g} / \mathrm{mL})$ assays. In contrast, the FRAP assay was lower $(134.1 \pm 0.1 \mu \mathrm{mol}$ Trolox equivalent per $\mathrm{g}$ of dry plant) than those of Chilean G. phillyreifolia berries $(6019.6 \pm 42.0 \mu \mathrm{mol}$ Trolox equivalent/g) [11]. Recently, TEAC, DPPH, and CUPRAC experiments were investigated from G. poeppigii samples [12]. In the ORAC assay, the G. pumila value was $4251.6 \mu \mathrm{mol}$ Trolox equivalent per $g$ of dry plant. In addition, G. poeppigii berries showed the best results in the ORAC (2412-6145 $\mu \mathrm{mol}$ Trolox equivalent per g of dry plant) and DPPH (IC 50 from $10.3 \pm 0.5 \mu \mathrm{g} / \mathrm{mL}$ ) experiments [11]. The antioxidant activity was also evaluated for Chilean G. mucronata $(28.9 \pm 4.2 \mu \mathrm{mol} \mathrm{TEAC/g})$ and G. antarctica $(20.3 \pm 5.2 \mu \mathrm{mol}$ TEAC/g) using Trolox equivalent antioxidant capacity (TEAC) assays [14].

Previous studies with others berries such as calafate (Berberis microphylla) and zarzaparilla (Ribes magellanicum) showed higher antioxidant capacities estimated by TEAC; this is attributed to the presence of higher concentrations of anthocyanins in the fruits [14]. In similar studies, the blueberry Vaccinium myrtillus was evaluated regarding its antioxidant capacity and the total phenolic content. The antioxidant activity was higher in the colored berries than in the white berries and the total phenolic content was also higher [61]. The Maqui berry (Aristotelia chilensis) has demonstrated a great proportion of polyphenolic compounds (phenolic acids, flavonoids, and anthocyanins) as antioxidant agents [62]. 
Finally, it can be considered that the antioxidant capacity observed in the G. pumila study may be useful as a protection against free radicals; these results could be explained by the presence of different types of phenolic compounds with antioxidant properties and by the comparison based on other berries.

Table 2. Total phenolic, flavonoid, and anthocyanin content, and antioxidant activity of Gaultheria pumila berries.

\begin{tabular}{|c|c|c|}
\hline Assay & Gaultheria pumila & Standard \\
\hline Total phenolics A & $189.2 \pm 0.2$ & - \\
\hline Total flavonoids ${ }^{B}$ & $51.8 \pm 0.1$ & - \\
\hline Total anthocyanin C & $47.3 \pm 0.2$ & - \\
\hline FRAP $^{D}$ & $134.1 \pm 0.1$ & - \\
\hline ORAC $^{\mathrm{E}}$ & $4251.6 \pm 16.9$ & - \\
\hline $\mathrm{DPPH}^{\mathrm{F}}$ & $92.8 \pm 0.1$ & Gallic acid: $0.55 \pm 0.1$ \\
\hline
\end{tabular}

All values are expressed as means $\pm \mathrm{SD}(n=3) .{ }^{\mathrm{A}}$ is expressed in mg gallic acid equivalent per $\mathrm{g}$ of extract. ${ }^{\mathrm{B}}$ is expressed in $\mathrm{mg}$ quercetin equivalent per $\mathrm{g}$ of extract. ${ }^{C}$ is expressed in $\mathrm{mg}$ cianydin-3-glucoside equivalent per $g$ of extract. $\mathrm{D}$ is expressed in $\mu \mathrm{mol}$ Trolox equivalent per $\mathrm{g}$ of dry plant. $\mathrm{E}$ is expressed in $\mu \mathrm{mol}$ Trolox equivalent per $\mathrm{g}$ of dry plant. $\mathrm{F}$ is expressed as $\mathrm{IC}_{50}$ in $\mu \mathrm{g}$ of extract or standard per mL. Abbreviations: FRAP, ferric reducing/antioxidant power; ORAC, oxygen radical absorbance capacity; ABTS, 2, 20-azino-bis (3-ethylbenzothiazoline-6-sulfonic acid; and DPPH, 2, 2-diphenyl-1-picryl-hydrazyl-hydrate.

\subsection{Enzymatic Inhibitory Activity}

Gaultheria pumila berries were assessed in vitro for cholinesterase and tyrosinase inhibitory potential. To the best of our knowledge, no previous reports regarding anti-enzymatic potential have been conducted in this species. The results are summarized in Table 3 and are expressed as $\mathrm{IC}_{50}$ values $(\mu \mathrm{g} / \mathrm{mL})$. The use of berries has been important over the years to prevent neurodegenerative diseases due to their high content of phenolic compounds [25]. G. pumila showed moderate activity against $\mathrm{AChE}\left(\mathrm{IC}_{50}=7.7 \pm 0.3 \mu \mathrm{g} / \mathrm{mL}\right)$, $\mathrm{BChE}\left(\mathrm{IC}_{50}=34.5 \pm 0.5 \mu \mathrm{g} / \mathrm{mL}\right)$, and tyrosinase $\left(\mathrm{IC}_{50}=3.3 \pm 0.2 \mu \mathrm{g} / \mathrm{mL}\right)$ in the enzymatic assays. Regarding the metabolites identified in the extract of G. pumila, some reports indicated that, for example, cyanidin-3-O-glucoside showed properties against mono amine oxidase-A, tyrosinase, and fatty acid amide hydrolase (FAAH) enzymes, whereas no activity was found against AChE [63]. In docking studies, chlorogenic acid was demonstrated to inhibit cholinesterase enzymes [64]. Isoquercitrin exhibited potent alpha-glucosidase, tyrosinase, and xanthine oxidase enzyme-inhibitory activities [65]. Delphinidin-3-O-glucoside, cyanindin-3-O-glucoside, peonidin-3-O-glucoside, and malvidin-3-O-glucoside were the principal anthocyanin detected in red wines from Serbia vineyards, which were related to AChE inhibitory activity [66]. Quercetin derivatives (quercetin-3-O-glucoside) and other flavonoids were identified as kaempferol and isorhamnetin derivates from Hippophae rhamnoides berries, which have demonstrated AChE and BChE inhibitory activities [67]. Regarding chlorogenic acid, BChE inhibitory activity has been reported [68]. From the Gaultheria species, tyrosinase inhibitory activity has been reported in Gaultheria erecta, suggesting properties against skin aging [60]. Conversely, BChE inhibitory activity $(35.52 \pm 1.17 \mu \mathrm{g} / \mathrm{mL})$ has been reported for Gaultheria trichophylla [69]. These reports highlight the importance of metabolites contained in Gaultheria fruits that could be suitable for use in the prevention of neurodegenerative diseases.

Table 3. Enzymatic inhibitory activity of Gaultheria pumila berries.

\begin{tabular}{|c|c|c|c|}
\hline Assay & $\begin{array}{l}\text { AChE Inhibition } \\
\text { IC }_{50}(\mu \mathrm{g} / \mathrm{mL})\end{array}$ & $\begin{array}{c}\text { BChE Inhibition } \\
\text { IC }_{50}(\mu \mathrm{g} / \mathrm{mL})\end{array}$ & $\begin{array}{l}\text { Tyrosinase Inhibition } \\
\operatorname{IC}_{50}(\mu \mathrm{g} / \mathrm{mL})\end{array}$ \\
\hline Gaultheria pumila & $7.7 \pm 0.3$ & $34.5 \pm 0.5$ & $3.3 \pm 0.2$ \\
\hline Galanthamine & $0.3 \pm 0.3$ & $3.82 \pm 0.2$ & - \\
\hline Kojic acid & - & - & $10.0 \pm 1.9$ \\
\hline
\end{tabular}

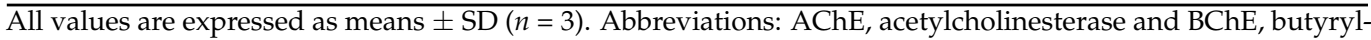
cholinesterase. 


\subsection{Docking Studies}

Five selected major compounds according to the UHPLC chromatogram (Figure 3) obtained from G. pumila berries extract as well as the known cholinesterase and tyrosinase inhibitors, galantamine and kojic acid, respectively, were subjected to docking assays in the acetylcholinesterase catalytic site, butyrylcholinesterase catalytic site, and tyrosinase catalytic site in order to rationalize their pharmacological results and analyze their protein molecular interactions in light of the experimental inhibition activities obtained (Table 3). The best docking binding energies expressed in $\mathrm{kcal} / \mathrm{mol}$ of each selected compound are shown below.

\subsubsection{Acetylcholinesterase (TcAChE) Docking Results}

Table 4 shows binding energies of Scupolin I, Unedide, Nuzhenal B, Myricetin O-rhamnoside, and Luteolin 7-glucuronide. All the aforementioned compounds displayed good energy descriptors over the acetylcholinesterase enzyme. Some of them showed binding energies in a similar range compared to galantamine and in case of Nuzhenal B, Myricetin 3-rhamnoside, and Luteolin 7-glucuronide, a better energy profile was even obtained. The latter would explain the higher potency (less $\mathrm{IC}_{50}$ value) over acetylcholinesterase than as presented by the berries extract over butyrylcholinesterase $\left(\mathrm{IC}_{50}=34.52 \pm 0.05\right)$. Even though galantamine exhibited a binding energy of $-12.989 \mathrm{kcal} / \mathrm{mol}$ and Nuzhenal B or Myricetin O-rhamnoside possessed slightly better energy parameters, the fact that the aqueous berries extract contained other active compounds lead into a competition among all of them for the acetylcholinesterase catalytic site; a refined result cannot be obtained. Nonetheless, it is clear that the good energies presented by these major compounds in the extract could be the responsible for the strong inhibitory effect shown over the enzyme. In terms of molecular interactions among each compound and the residues of the catalytic site, mainly all derivatives performed hydrogen bond interactions with the catalytic amino acids.

Table 4. Binding energies obtained from docking experiments of selected major compounds in Gaultheria pumila berries extract, as well as the known inhibitors galantamine and kojic acid over acetylcholinesterase (TcAChE), butyrylcholinesterase, $(h \mathrm{BChE})$ and tyrosinase accordingly.

\begin{tabular}{cccc}
\hline Compound & $\begin{array}{c}\text { Binding Energy (kcal/mol) } \\
\text { Acetylcholinesterase }\end{array}$ & $\begin{array}{c}\text { Binding Energy (kcal/mol) } \\
\text { Butyrylcholinesterase }\end{array}$ & $\begin{array}{c}\text { Binding Energy (kcal/mol) } \\
\text { Tyrosinase }\end{array}$ \\
\hline Scupolin I (29) & -10.582 & -7.361 & -4.303 \\
Unedide (2) & -12.081 & -10.972 & -10.643 \\
Nuzhenal B (21) & -15.289 & -11.079 & -10.576 \\
Myricetin O-rhamnoside (14) & -15.175 & -11.581 & -10.528 \\
Luteolin 7-glucuronide (19) & -13.757 & -11.777 & -11.323 \\
Galantamine & -12.989 & -7.125 & - \\
Kojic acid & - & - & -6.050 \\
\hline
\end{tabular}

In this sense, the compounds that showed better energies also exhibited a greater amount of hydrogen bond interactions. Scupolin I performed three different hydrogen bond interactions (Figure 4A), all of them are carried out by oxygen atoms; one through a methoxy group and the other two through the epoxide function, and the ester carbonyl resembled its structure. Unedide also showed three hydrogen bond interactions where its hydroxyl groups are implied; this allows a protein-inhibitor complex stabilization through the amino acids of Trp84, Gly117, and Glu199 (Figure 4B). The good binding energy values shown by Nuzhenal B and Myricetin O-rhamnoside may be supported by the higher amount of hydrogen bond interactions performed, as well as the extra $\pi-\pi$ interaction that both derivatives carry out into the acetylcholinesterase catalytic site. Nuzhenal B exhibited three hydrogen bond interactions due to the hydroxyl groups at the glycoside moiety and also another specific hydrogen bond interaction between the deprotonated carboxylic group (carboxylate) of its branched aliphatic chain and the amino acid Tyr121 (Figure 4C). 
Moreover, the $\pi-\pi$ interaction mentioned above is also performed with Tyr121 through the phenolic ring of this residue and the presence of the phenolic ring into the Nuzhenal B structure. In the case of Myricetin O-rhamnoside, the largest number of hydrogen bond interactions are made by the hydroxy functions at the pyrogallol framework with the residues of Tyr70, Gln74, and Tyr334 of the acetylcholinesterase. In addition, another hydrogen bonding can be noted between a hydroxyl group of the $4 \mathrm{H}$-chromen-4-one core and the amino acid Tyr130. The $\pi-\pi$ interaction is carried out between the $4 \mathrm{H}$-chromen-4one and the aromatic indole ring of Trp84 (Figure 4D). Luteolin 7-glucuronide exhibited a good energy value of $-13.757 \mathrm{kcal} / \mathrm{mol}$ (Table 4 ). It is noteworthy that even though this derivative showed only three hydrogen bonding interactions, the fact that it also performed two different $\pi-\pi$ interactions, one through its $4 \mathrm{H}$-chromen-4-one moiety with the Trp 84 amino acid and the other by the catechol ring and the Tyr121 residue, most likely contributes to its energy profile (Figure $4 \mathrm{E}$ ).

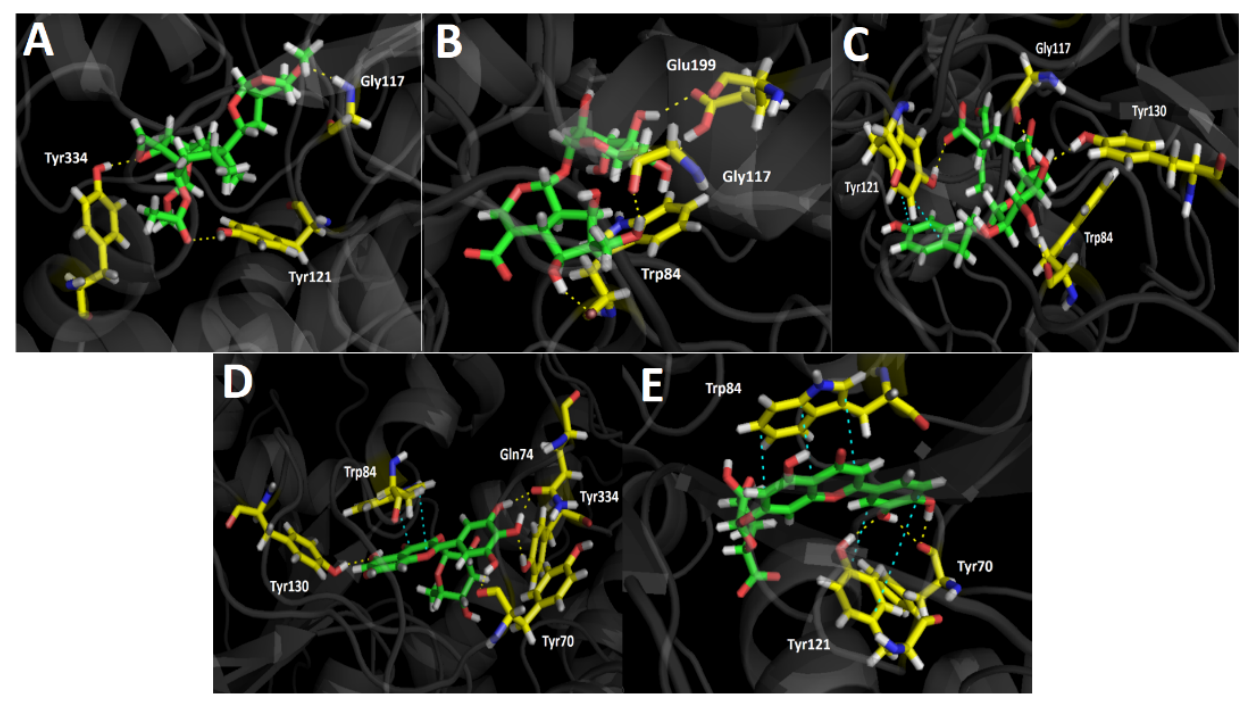

Figure 4. Predicted binding mode and predicted intermolecular interactions of the selected major compounds in Gaultheria pumila berries extract and the residues of the Torpedo Californica acetylcholinesterase (TcAChE) catalytic site. Yellow dotted lines indicate hydrogen bond interactions and cyan dotted lines represent $\pi-\pi$ interactions. (A) Scupolin I in the catalytic site; (B) Unedide in the catalytic site; (C) Nuzhenal B in the catalytic site; (D) Myricetin O-rhamnoside in the catalytic site; and (E) Luteolin 7-glucuronide in the catalytic site.

\subsubsection{Butyrylcholinesterase (hBuChE) Docking Results}

Binding energies from docking assays over butyrylcholinesterase ( $h \mathrm{BuChE})$ of the selected major compounds from Gaultheria pumila berries extract showed to be poorer compared to those in acetylcholinesterase (TcAChE). Almost all compounds present a good binding energy profile, except for Scupolin I as in acetylcholinesterase (Table 4). Although tested derivatives show slightly better energies compared to galantamine, not a wide difference is contemplated, suggesting the reason for the closer $\mathrm{IC}_{50}$ values between galantamine and the G. pumila berries extract in our inhibition assays. In fact, both half-maximal inhibitory concentrations are in the same order of magnitude $\left(\mathrm{IC}_{50}=34.52 \pm 0.05\right.$ for the extract and $\mathrm{IC}_{50}=3.82 \pm 0.08$ for galantamine). As in acetylcholinesterase docking assays, the intermolecular interactions in the butyrylcholinesterase catalytic site that predominates are hydrogen bond interactions and a $\pi-\pi$ interaction in the case of Nuzhenal B. Scupolin I binding descriptors over butyrylcholinesterase share some similarities to those showed in acetylcholinesterase docking results for this derivative. Indeed, Scupolin I shows three different hydrogen bond interactions performed by the oxygen atoms of one of the alicyclic tetrahydrofuran rings contained in its structure and the esther carbonyl with Ser198, Trp82, and Trp430 (Figure 5A). Unedide, which exhibited a better binding energy than Scupolin I, 
also presented more hydrogen bond interactions, mainly through the hydrogen atoms of the different hydroxyl functions at its glycoside moiety with Trp82 and Tyr128, as well as with the oxygen atoms of the deprotonated carboxylate of Glu197. Furthermore, it can be seen that two other hydrogen bond interaction were performed by a hydroxyl group and a carboxylate (contained at the hexahydrocyclopenta[b]pyrane core of Unedide) with Ser198 and Thr120, respectively (Figure 5B).

Due to the fact that Nuzhenal B bore a glycoside moiety in its structure, this derivative possesses the ability to carry out hydrogen bond interactions through the hydroxyl groups present at this core, but only one of these interactions are displayed by a hydroxy group of this framework with the amino acid Asp70 (Figure 5C). Given the above, Nuzhenal B arranged into the catalytic site through hydrogen bondings performed by a phenolic group and a carboxylate function of its structure. The residues implied in the four interactions mentioned above are Tyr128, Glu187, His438, and Gly117 (Figure 5C). Moreover, Nuzhenal B showed a $\pi-\pi$ interaction with the indole ring of Trp82 and the phenolic moiety of its structure as already aforementioned. Myricetin O-rhamnoside and Luteolin 7-glucuronide, which share the $4 H$-chromen-4-one framework in their structures, also showed the best binding energy profiles. The latter could be attributed due to the fact that both derivatives showed more than five hydrogen bond interactions with the different residues of the butyrylcholinesterase catalytic site, either through the hydroxy functions at the pyrogallol framework in Myricetin O-rhamnoside or through the hydroxy groups at the catechol ring in Luteolin 7-glucuronide (Figure 5D,E). Additionally, the presence of glycosidic portions in both derivatives also allowed it to perform hydrogen bond interactions, but this core in Luteolin 7-glucuronide becomes more relevant as it carried out four interactions through its hydroxyl functions, alongside a special hydrogen bonding with the residue Ser198 and the deprotonated carboxylate that this moiety possesses (Figure 5E).
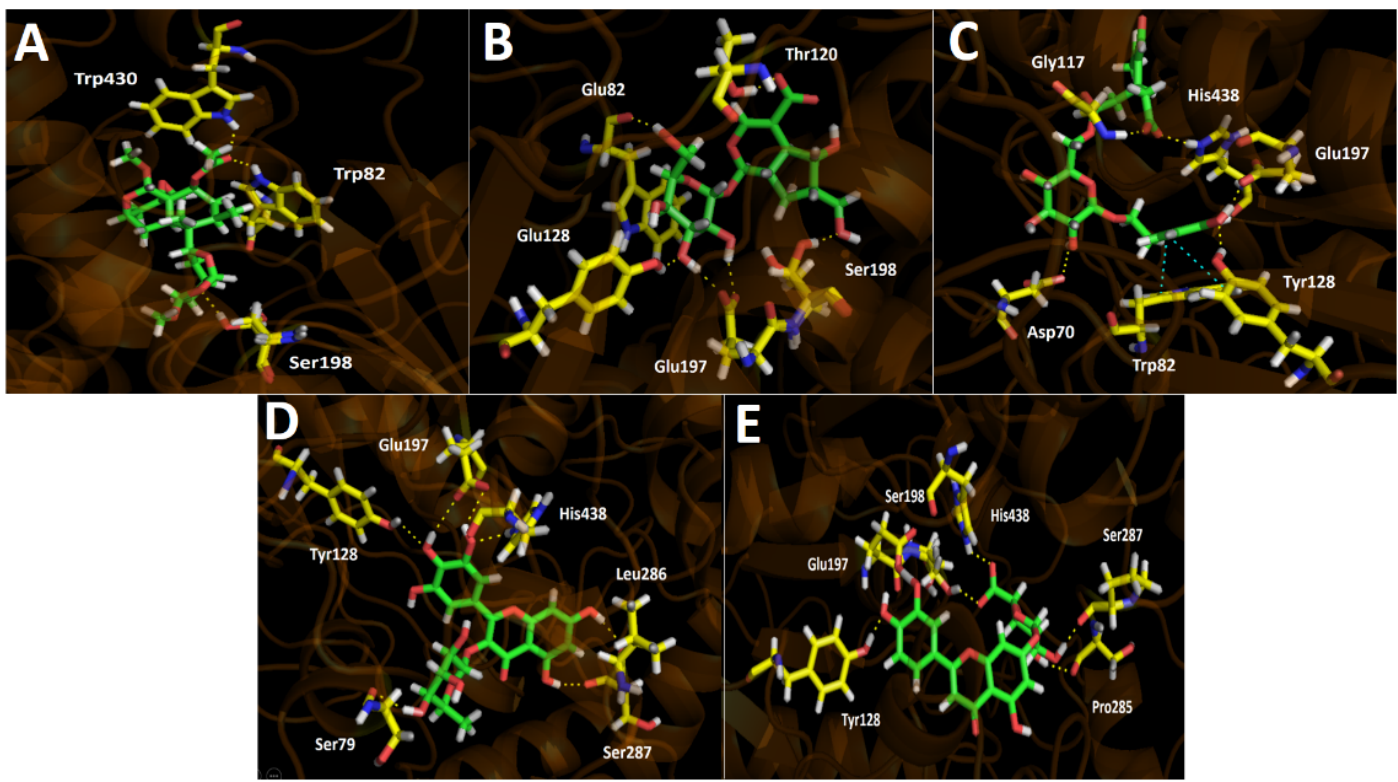

Figure 5. Predicted binding mode and predicted intermolecular interactions of the selected major compounds in Gaultheria pumila berries extract and the residues of the human butyrylcholinesterase $(h \mathrm{BuChE})$ catalytic site. Yellow dotted lines indicate hydrogen bond interactions and cyan dotted lines represent $\pi-\pi$ interactions. (A) Scupolin I in the catalytic site; (B) Unedide in the catalytic site; (C) Nuzhenal B in the catalytic site; (D) Myricetin O-rhamnoside in the catalytic site; and (E) Luteolin 7-glucuronide in the catalytic site. 


\subsubsection{Tyrosinase Docking Results}

Inhibition assays of Gaultheria pumila berries extract over tyrosinase turned out to be more potent than the known inhibitor kojic acid by three-folds. Even though the precise reaction mechanism of tyrosinase is unclear and no information is available about the binding mode of many substrates, the higher potency shown by our berries extract could be explained by the docking results summarized in Table 4 and Figure 6 .

Regarding the intermolecular interactions of the selected major compounds obtained from the UHPLC chromatogram, docking descriptors suggest that the main inhibitory activity would lie in Nuzhenal B, Myricetin O-rhamnoside, and Luteolin 7-glucuronide derivatives. Indeed, Scupolin I docking assays over tyrosinase, just like in acetylcholinesterase and butyrylcholinesterase, showed a deficient binding energy of $-4.303 \mathrm{kcal} / \mathrm{mol}$ and no contributing interactions were present among the residues of the catalytic site and Scupolin I structure, except with some hydrophobic amino acids. This phenomenon could be due to the lack of chemical groups by Scupolin I capable of performing other sorts of interactions such as $\pi-\pi$, T-shaped, or $\pi$-cation interaction. Thus, probably this compound would not contribute to the enzyme inhibition in a significant manner, even if it is in high proportion in the extract. As tyrosinase bore two copper cations leading to a binuclear copper-binding site in which three histidine residues coordinate each ion (His61, His85, and His94 for one copper cation, and His259, His263, and His296 for the other), these metal atoms could play a key role in the stabilization of some protein-inhibitor complexes with the different substrates. In this sense, Unedide not only carried out three hydrogend bond interactions among its hydroxyl groups and the residues of Gly281, Ser282, and Arg268, but also a salt bridge between one of the copper ions and the deprotonated carboxylate at its hexahydrocyclopenta[b]pyrane core (Figure 6B). In the same way, Nuzhenal B and Luteolin 7-glucuronide also exhibited salt bridge interactions between their carboxylate groups and one copper ion. The salt bridges aforementioned by Nuzhenal B and Luteolin 7-glucuronide are possible due to the fact that the first one bore a carboxylate function in its branched aliphatic chain and the second one on its glycoside moiety. Conversely, Myricetin O-rhamnoside, due to a lack of a carboxylic acid group on its structure, would be unable to perform a salt bridge interaction with the tyrosine catalytic site (Figure 6D). In addition to the salt bridge interactions of the three derivatives already described, it should be noted that docking assays revealed that Nuzhenal B also carried out four hydrogen bond interactions among the hydroxyl groups at the phenol moiety and at the glycoside core, as well as with the oxygen atom of the esther carbonyl. The organic functions of Nuzhenal B mentioned above interacted with His85, Glu322, His244, and Asn260. Myricetin Orhamnoside showed hydrogen bond interactions with His244, Asn260, Arg268, Gly281, and Val283, and also a $\pi-\pi$ interaction with the imidazole ring of His244 was performed. This last interaction could be improving the affinity of this compound for the tyrosinase catalytic site. Luteolin 7-glucuronide was the only derivative that showed, in addition to the hydrogen bondings, a $\pi$-cation interaction between its $4 H$-chromen-4-one framework and the cationic protonated side chain of Arg268 (Figure 6E).

In order to summarize the information, the main interactions of the compounds with the best binding energy profile were performed, displayed in a two-dimensional diagram below (Supplementary Material). 

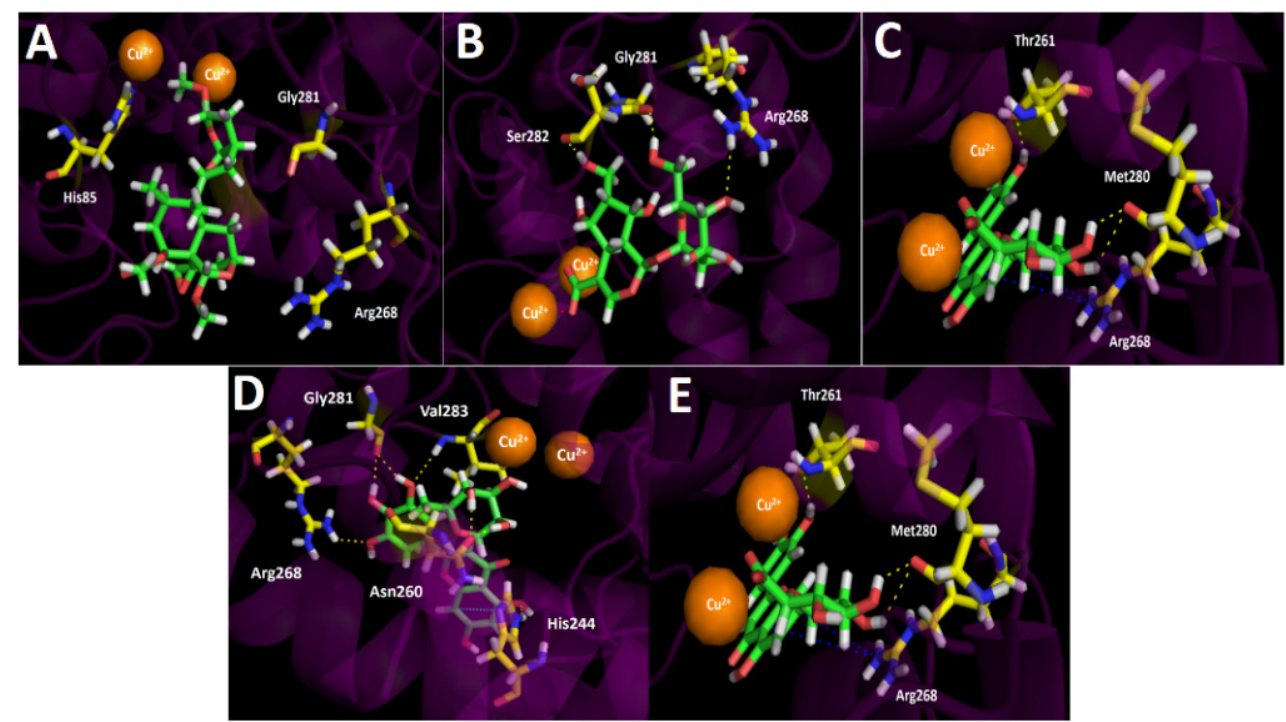

Figure 6. Predicted binding mode and predicted intermolecular interactions of the selected major compounds in Gaultheria pumila berries extract and the residues of the Agaricus bisporus mushroom tyrosinase catalytic site. Yellow dotted lines indicate hydrogen bond interactions, cyan dotted lines represent $\pi-\pi$ interactions, red dotted lines indicate salt bridge interactions, and blue dotted lines indicate $\pi$-cation interactions. (A) Scupolin I in the catalytic site; (B) Unedide in the catalytic site; (C) Nuzhenal B in the catalytic site; (D) Myricetin O-rhamnoside in the catalytic site; and (E) Luteolin 7-glucuronide in the catalytic site.

\subsection{Antiproliferative Activity}

The antiproliferative activity of G. pumila berries was evaluated against six human solid tumor cell lines. The results show that G. pumila was not able to induce antiproliferative effects under the standard protocol conditions $\left(\mathrm{GI}_{50}\right.$ and TGI $>250 \mu \mathrm{g} / \mathrm{mL}$ in all cell lines). For some compounds contained in the extract, the literature reports activity against cancer cell lines. Several anthocyanins showed cardioprotective, neuroprotective, antidiabetic, and anticancer effects [70]. Anthocyanins such as cyanidin-3-O-glucoside and delphinidin-3-O-glucoside prevent tumor progression by inhibiting angiogenesis through VEGFR-2 downregulation using cell models [71]. Furthermore, it has been reported that these compounds, which are also present in blackcurrant berries, exhibited antiproliferative properties on several solid tumor cancer cells [72]. In other studies, chlorogenic acid was attributed to have effects against breast cancer cell growth [73], quercitrin to have antiproliferative and apoptotic effects on lung cancer cells by modulating the immune response [74], and aglycone quercetin to be able to exert antitumor action by inhibiting cell proliferation, inhibiting angiogenesis, and preventing the progression of metastasis against various cancers [75]. For example, previous studies have found that the combination of quercetin with ionizing radiation showed a greater response against colon cancer stem cells. In addition, the combination of quercetin with resveratrol in a dermal gel favored penetration into deeper layers of the skin and thus can serve as a promising component to be used in formulations for the treatment of skin cancer [76,77]. Other results showed that quercetin exhibits inhibitory activity against the growth of metastatic ovarian cancer cells [78]. In another study, scutellarin derivatives were demonstrated to be active against Jurkat, HCT-116, and MDA-MB-231 cancer cell lines [79]. Our results showed no cytotoxic activity against A549 (lung), HBL-100 (breast), HeLa (cervix), SW1573 (lung), T-47D (breast), and WiDr (colon) cell lines. However, these previous results showed that some individual compounds contained in G. pumila berries could be used for the prevention of cancer due to its cytotoxic activities. 


\section{Conclusions}

The antioxidant, antiproliferative, and enzyme inhibition potential, and the chemical fingerprinting of G. pumila berries were investigated for the first time. High resolution mass spectrometry (UHPLC-DAD-Orbitrap-MS) was used to detect 36 metabolites. To the best of our knowledge, this is the first investigation on the inhibitory activities (against cholinesterase and tyrosinase) and antiproliferative screening of these berries, updating the knowledge on the biological profile of this interesting species. The results from the enzyme inhibition studies demonstrated a moderate inhibition and did not show antiproliferative activity. Docking studies of the selected major compounds indicated that hydrogen bond interactions and a $\pi-\pi$ interaction are predominant over acetylcholinesterase and butyrylcholinesterase, while a salt bridge interaction is predominant in the case of tyrosinase. Bioassay-guided fractionation and isolation of major compounds are needed to further characterize the molecule(s) responsible for the selected biological activities.

Supplementary Materials: The following are available online at https:/ /www.mdpi.com/article/10 .3390/metabo11080523/s1, Figure S1: High resolution UHPLC-PDA-Orbitrap-MS identification of metabolites in Gaultheria pumila fruits, Figure S2: Compounds subjected to docking assays into the corresponding catalytic sites of acetylcholinesterase, butyrylcholinesterase, and tyrosinase, Figure S3: Two-dimensional diagram.

Author Contributions: C.F.-G. and L.Q.-R. conceived the research idea. C.F.-G. and L.Q.-R. collected the fruits (berries) and wrote the paper. C.F.-G. and L.Q.-R. performed the antioxidant experiments and wrote the results. C.F.-G., L.Q.-R. and E.S. performed the enzymatic experiments and wrote the results. J.R.-P. performed the docking studies and wrote the results. A.P. and J.M.P. performed the antiproliferative experiments. M.J.S. and C.F.-G. analyzed the data of the HPLC-ESI-MS/MS analysis and wrote the results. All authors have approved the submission. All authors have read and agreed to the published version of the manuscript.

Funding: C.F.-G. acknowledges Postdoctorado FONDECYT 3190794. This research received funds from Universidad San Sebastián (Project VRIDFAI20/11 to L.Q.-R.). MS acknowledges FONDECYT 1180059. A.P. and J.M.P. give thanks to the Spanish Government for the financial support through project PGC2018-094503-B-C22 (MCIU/AEI/FEDER, UE). A.P. thanks the EU Social Fund (FSE) and the Canary Islands ACIISI for the predoctoral grant TESIS2020010055.

Institutional Review Board Statement: Not applicable.

Informed Consent Statement: Not applicable.

Data Availability Statement: Data from the study is available on the request from a corresponding author.

Acknowledgments: Milena Ríos is acknowledged for her help in the antioxidant assays.

Conflicts of Interest: The authors declare no conflict of interest. The funding sponsors had no role in the design of the study; in the collection, analysis, and interpretation of data; in the writing of the manuscript; or in the decision to publish the results.

\section{References}

1. Silva, S.; Costa, E.M.; Veiga, M.; Morais, R.M.; Calhau, C.; Pintado, M. Health promoting properties of blueberries: A review. Crit. Rev. Food Sci. Nutr. 2020, 60, 181-200. [CrossRef]

2. Speer, H.; D'Cunha, N.M.; Alexopoulos, N.I.; McKune, A.J.; Naumovski, N. Anthocyanins and Human Health-A Focus on Oxidative Stress, Inflammation and Disease. Antioxidants 2020, 9, 366. [CrossRef] [PubMed]

3. López, J.; Vera, C.; Bustos, R.; Florez-Mendez, J. Native berries of Chile: A comprehensive review on nutritional aspects, functional properties, and potential health benefits. J. Food Meas. Charact. 2021, 15, 1139-1160. [CrossRef]

4. Luo, B.; Gu, R.; Kennelly, E.J.; Long, C. Gaultheria Ethnobotany and Bioactivity: Blueberry Relatives with Anti-inflammatory, Antioxidant, and Anticancer Constituents. Curr. Med. Chem. 2017, 25, 5168-5176. [CrossRef] [PubMed]

5. Liu, W.-R.; Qiao, W.-L.; Liu, Z.-Z.; Wang, X.-H.; Jiang, R.; Li, S.-Y.; Shi, R.-B.; She, G.-M. Gaultheria: Phytochemical and Pharmacological Characteristics. Molecules 2013, 18, 12071-12108. [CrossRef]

6. Pandey, B.P.; Thapa, R.; Upreti, A. Chemical composition, antioxidant and antibacterial activities of essential oil and methanol extract of Artemisia vulgaris and Gaultheria fragrantissima collected from Nepal. Asian Pac. J. Trop. Med. 2017, 10, 952-959. [CrossRef] 
7. Michel, P.; Dobrowolska, A.; Kicel, A.; Owczarek, A.; Bazylko, A.; Granica, S.; Piwowarski, J.P.; Olszewska, M.A. Polyphenolic profile, antioxidant and anti-inflammatory activity of eastern teaberry (Gaultheria procumbens L.) leaf extracts. Molecules 2014, 19, 20498-20520. [CrossRef]

8. Shen, B.-B.; Yang, Y.-P.; Yasamin, S.; Liang, N.; Su, W.; Chen, S.-H.; Wang, X.-J.; Wang, W. Analysis of the Phytochemistry and Bioactivity of the Genus Polygonum of Polygonaceae. Digit. Chin. Med. 2018, 1, 19-36. [CrossRef]

9. Ferguson, A.; Carvalho, E.; Gourlay, G.; Walker, V.; Martens, S.; Salminen, J.P.; Constabel, C.P. Phytochemical analysis of salal berry (Gaultheria shallon Pursh.), a traditionally-consumed fruit from western North America with exceptionally high proanthocyanidin content. Phytochemistry 2018, 147, 203-210. [CrossRef]

10. Teillier, S.; Escobar, F. Revision of the genus of gaultheria L. (Ericaceae) in Chile. Gayana Bot. 2013, 70, 136-153. [CrossRef]

11. Mieres-Castro, D.; Schmeda-Hirschmann, G.; Theoduloz, C.; Gómez-Alonso, S.; Pérez-Navarro, J.; Márquez, K.; Jiménez-Aspee, F. Antioxidant activity and the isolation of polyphenols and new iridoids from Chilean Gaultheria phillyreifolia and G. poeppigii berries. Food Chem. 2019, 291, 167-179. [CrossRef]

12. Oyarzún, P.; Cornejo, P.; Gómez-Alonso, S.; Ruiz, A. Influence of Profiles and Concentrations of Phenolic Compounds in the Coloration and Antioxidant Properties of Gaultheria poeppigii Fruits from Southern Chile. Plant Foods Hum. Nutr. 2020, 75, 532-539. [CrossRef]

13. Mieres-Castro, D.; Schmeda-Hirschmann, G.; Theoduloz, C.; Rojas, A.; Piderit, D.; Jiménez-Aspee, F. Isolation and characterization of secondary metabolites from Gaultheria tenuifolia berries. J. Food Sci. 2020, 85, 2792-2802. [CrossRef] [PubMed]

14. Ruiz, A.; Hermosín-Gutiérrez, I.; Vergara, C.; von Baer, D.; Zapata, M.; Hitschfeld, A.; Obando, L.; Mardones, C. Anthocyanin profiles in south Patagonian wild berries by HPLC-DAD-ESI-MS/MS. Food Res. Int. 2013, 51, 706-713. [CrossRef]

15. Ruiz, A.; Bustamante, L.; Vergara, C.; Von Baer, D.; Hermosín-Gutiérrez, I.; Obando, L.; Mardones, C. Hydroxycinnamic acids and flavonols in native edible berries of South Patagonia. Food Chem. 2015, 167, 84-90. [CrossRef]

16. Villagra, E.; Campos-Hernandez, C.; Cáceres, P.; Cabrera, G.; Bernardo, Y.; Arencibia, A.; Carrasco, B.; Caligari, P.D.S.; Pico, J.; García-Gonzales, R. Morphometric and phytochemical characterization of chaura fruits (Gaultheria pumila): A native Chilean berry with commercial potential. Biol. Res. 2014, 47, 26. [CrossRef] [PubMed]

17. Rocchetti, G.; Chiodelli, G.; Giuberti, G.; Ghisoni, S.; Baccolo, G.; Blasi, F.; Montesano, D.; Trevisan, M.; Lucini, L. UHPLC-ESIQTOF-MS profile of polyphenols in Goji berries (Lycium barbarum L.) and its dynamics during in vitro gastrointestinal digestion and fermentation. J. Funct. Foods 2018, 40, 564-572. [CrossRef]

18. Liu, S.; Marsol-Vall, A.; Laaksonen, O.; Kortesniemi, M.; Yang, B. Characterization and Quantification of Nonanthocyanin Phenolic Compounds in White and Blue Bilberry (Vaccinium myrtillus) Juices and Wines Using UHPLC-DAD-ESI-QTOF-MS and UHPLC-DAD. J. Agric. Food Chem. 2020, 68, 7734-7744. [CrossRef]

19. Barrientos, R.; Fernández-Galleguillos, C.; Pastene, E.; Simirgiotis, M.; Romero-Parra, J.; Ahmed, S.; Echeverría, J. Metabolomic Analysis, Fast Isolation of Phenolic Compounds, and Evaluation of Biological Activities of the Bark from Weinmannia trichosperma Cav. (Cunoniaceae). Front. Pharmacol. 2020, 11, 780. [CrossRef]

20. Barrientos, R.E.; Ahmed, S.; Cortés, C.; Fernández-Galleguillos, C.; Romero-Parra, J.; Simirgiotis, M.J.; Echeverría, J. Chemical Fingerprinting and Biological Evaluation of the Endemic Chilean Fruit Greigia sphacelata (Ruiz and Pav.) Regel (Bromeliaceae) by UHPLC-PDA-Orbitrap-Mass Spectrometry. Molecules 2020, 25, 3750. [CrossRef]

21. Brito, A.; Areche, C.; Sepúlveda, B.; Kennelly, E.J.; Simirgiotis, M.J. Anthocyanin characterization, total phenolic quantification and antioxidant features of some chilean edible berry extracts. Molecules 2014, 19, 10936-10955. [CrossRef]

22. Simirgiotis, M.; Quispe, C.; Bórquez, J.; Areche, C.; Sepúlveda, B. Fast Detection of Phenolic Compounds in Extracts of Easter Pears (Pyrus communis) from the Atacama Desert by Ultrahigh-Performance Liquid Chromatography and Mass Spectrometry (UHPLC-Q/Orbitrap/MS/MS). Molecules 2016, 21, 92. [CrossRef] [PubMed]

23. Larrazábal-Fuentes, M.J.; Fernández-Galleguillos, C.; Palma-Ramírez, J.; Romero-Parra, J.; Sepúlveda, K.; Galetovic, A.; González, J.; Paredes, A.; Bórquez, J.; Simirgiotis, M.J.; et al. Chemical Profiling, Antioxidant, Anticholinesterase, and Antiprotozoal Potentials of Artemisia copa Phil. (Asteraceae). Front. Pharmacol. 2020, 11, 594174. [CrossRef] [PubMed]

24. Jiménez-Aspee, F.; Quispe, C.; Soriano, M.d.P.C.; Fuentes Gonzalez, J.; Hüneke, E.; Theoduloz, C.; Schmeda-Hirschmann, G. Antioxidant activity and characterization of constituents in copao fruits (Eulychnia acida Phil., Cactaceae) by HPLC-DADMS/MSn. Food Res. Int. 2014, 62, 286-298. [CrossRef]

25. Simirgiotis, M.J.; Bórquez, J.; Schmeda-Hirschmann, G. Antioxidant capacity, polyphenolic content and tandem HPLCDAD-ESI/MS profiling of phenolic compounds from the South American berries Luma apiculata and L. chequén. Food Chem. 2013, 139, 289-299. [CrossRef]

26. Ramirez, J.E.; Zambrano, R.; Sepúlveda, B.; Kennelly, E.J.; Simirgiotis, M.J. Anthocyanins and antioxidant capacities of six Chilean berries by HPLC-HR-ESI-ToF-MS. Food Chem. 2015, 176, 106-114. [CrossRef]

27. Huang, D.; Ou, B.; Hampsch-Woodill, M.; Flanagan, J.A.; Prior, R.L. High-throughput assay of oxygen radical absorbance capacity (ORAC) using a multichannel liquid handling system coupled with a microplate fluorescence reader in 96-well format. J. Agric. Food Chem. 2002, 50, 4437-4444. [CrossRef] [PubMed]

28. Zengin, G.; Uysal, S.; Ceylan, R.; Aktumsek, A. Phenolic constituent, antioxidative and tyrosinase inhibitory activity of Ornithogalum narbonense L. from Turkey: A phytochemical study. Ind. Crop. Prod. 2015, 70, 1-6. [CrossRef]

29. Petersson, G.A.; Bennett, A.; Tensfeldt, T.G.; Al-Laham, M.A.; Shirley, W.A.; Mantzaris, J. A complete basis set model chemistry. I. The total energies of closed-shell atoms and hydrides of the first-row elements. J. Chem. Phys. 1988, 89, 2193-2218. [CrossRef] 
30. Adamo, C.; Barone, V. Toward reliable density functional methods without adjustable parameters: The PBE0 model Seeking for parameter-free double-hybrid functionals: The PBE0-DH model Accurate excitation energies from time-dependent density functional theory: Assessing the PBE0. J. Chem. Phys. 1999, 110, 6158-6170. [CrossRef]

31. Greenblatt, H.M.; Kryger, G.; Lewis, T.; Silman, I.; Sussman, J.L. Structure of acetylcholinesterase complexed with (-)galanthamine at 2.3 A resolution. FEBS Lett. 1999, 463, 321-326. [CrossRef]

32. Nachon, F.; Carletti, E.; Ronco, C.; Trovaslet, M.; Nicolet, Y.; Jean, L.; Renard, P.Y. Crystal structures of human cholinesterases in complex with huprine $\mathrm{W}$ and tacrine: Elements of specificity for anti-Alzheimer's drugs targeting acetyl- and butyrylcholinesterase. Biochem. J. 2013, 453, 393-399. [CrossRef]

33. Ismaya, W.T.; Rozeboom, H.J.; Weijn, A.; Mes, J.J.; Fusetti, F.; Wichers, H.J.; Dijkstra, B.W. Crystal structure of agaricus bisporus mushroom tyrosinase: Identity of the tetramer subunits and interaction with tropolone. Biochemistry 2011, 50, 5477-5486. [CrossRef]

34. Berman, H.M.; Westbrook, J.; Feng, Z.; Gilliland, G.; Bhat, T.N.; Weissig, H.; Shindyalov, I.N.; Bourne, P.E. The Protein Data Bank. Nucleic Acids Res. 2000, 28, 235-242. [CrossRef] [PubMed]

35. Castillo, Q.A.; Triana, J.; Eiroa, J.L.; Calcul, L.; Rivera, E.; Wojtas, L.; Padrón, J.M.; Boberieth, L.; Keramane, M.; Abel-Santos, E.; et al. ent-Labdane Diterpenoids from the Aerial Parts of Eupatorium obtusissmum. J. Nat. Prod. 2016, 79, 907-913. [CrossRef] [PubMed]

36. Roy, R.; Pal, D.; Sur, S.; Mandal, S.; Saha, P.; Panda, C.K. Pongapin and Karanjin, furanoflavanoids of Pongamia pinnata, induce G2/M arrest and apoptosis in cervical cancer cells by differential reactive oxygen species modulation, DNA damage, and nuclear factor kappa-light-chain-enhancer of activated B cell signal. Phyther. Res. 2019, 33, 1084-1094. [CrossRef] [PubMed]

37. Picariello, G.; Sciammaro, L.; Siano, F.; Volpe, M.G.; Puppo, M.C.; Mamone, G. Comparative analysis of C-glycosidic flavonoids from Prosopis spp. and Ceratonia siliqua seed germ flour. Food Res. Int. 2017, 99, 730-738. [CrossRef]

38. Liu, J.; Hefni, M.E.; Witthöft, C.M. Characterization of Flavonoid Compounds in Common Swedish Berry Species. Foods 2020, 9, 358. [CrossRef]

39. Xu, G.L.; Liu, Z.Z.; Xie, M.; Zhang, X.; Yang, Y.; Yan, C.; Qiao, W.L.; Liu, W.R.; Jiang, R.; Wang, X.H.; et al. Salicylic Acid Derivatives and Other Components from Gaultheria trichoclada. Chem. Nat. Compd. 2016, 52, 301-303. [CrossRef]

40. Hajdú, Z.; Hohmann, J.; Forgo, P.; Martinek, T.; Dervarics, M.; Zupkó, I.; Falkay, G.; Cossuta, D.; Máthé, I. Diterpenoids and flavonoids from the fruits of Vitex agnus-castus and antioxidant activity of the fruit extracts and their constituents. Phyther. Res. 2007, 21, 391-394. [CrossRef]

41. Ono, M.; Masuoka, C.; Koto, M.; Tateishi, M.; Komatsu, H.; Kobayashi, H.; Igoshi, K.; Ito, Y.; Okawa, M.; Nohara, T. Antioxidant ortho-benzoyloxyphenyl acetic acid ester, vaccihein A, from the fruit of rabbiteye blueberry (Vaccinium ashei). Chem. Pharm. Bull. 2002, 50, 1416-1417. [CrossRef] [PubMed]

42. Willems, J.L.; Khamis, M.M.; Mohammed Saeid, W.; Purves, R.W.; Katselis, G.; Low, N.H.; El-Aneed, A. Analysis of a series of chlorogenic acid isomers using differential ion mobility and tandem mass spectrometry. Anal. Chim. Acta 2016, 933, 164-174. [CrossRef]

43. Jia, S.S.; Ma, C.M.; Li, Y.H.; Hao, J.H. Glycosides of phenolic acid and flavonoids from the leaves of Glycyrrhiza uralensis Ficsh. Yaо Хие Хие Вао 1992, 27, 441-444.

44. Llorent-Martinez, E.J.; Spinola, V.; Gouveia, S.; Castilho, P.C. HPLC-ESI-MSn characterization of phenolic compounds, terpenoid saponins, and other minor compounds in Bituminaria bituminosa. Ind. Crop. Prod. 2015, 69, 80-90. [CrossRef]

45. Petreska, J.; Stefkov, G.; Kulevanova, S.; Alipieva, K.; Bankova, V.; Stefova, M. Phenolic Compounds of Mountain Tea from the Balkans: LC/DAD/ESI/MSn Profile and Content. Nat. Prod. Commun. 2011, 6, 21-30. [CrossRef]

46. Tajner-Czopek, A.; Gertchen, M.; Rytel, E.; Kita, A.; Kucharska, A.Z.; Sokół-Łętowska, A. Study of antioxidant activity of some medicinal plants having high content of caffeic acid derivatives. Antioxidants 2020, 9, 412. [CrossRef]

47. Shrestha, A.; Rezk, A.; Said, I.H.; von Glasenapp, V.; Smith, R.; Ullrich, M.S.; Schepker, H.; Kuhnert, N. Comparison of the polyphenolic profile and antibacterial activity of the leaves, fruits and flowers of Rhododendron ambiguum and Rhododendron cinnabarinum. BMC Res. Notes 2017, 10, 1-11. [CrossRef]

48. Kyriacou, M.C.; El-Nakhel, C.; Pannico, A.; Graziani, G.; Soteriou, G.A.; Giordano, M.; Zarrelli, A.; Ritieni, A.; De Pascale, S.; Rouphael, Y. Genotype-Specific Modulatory Effects of Select Spectral Bandwidths on the Nutritive and Phytochemical Composition of Microgreens. Front. Plant Sci. 2019, 10, 1501. [CrossRef]

49. Nadeem, M.; Mumtaz, M.W.; Danish, M.; Rashid, U.; Mukhtar, H.; Irfan, A.; Anwar, F.; Saari, N. UHPLC-QTOF-MS/MS metabolites profiling and antioxidant/antidiabetic attributes of Cuscuta reflexa grown on Casearia tomentosa: Exploring phytochemicals role via molecular docking. Int. J. Food Prop. 2020, 23, 918-940. [CrossRef]

50. Gómez-Romero, M.; Segura-Carretero, A.; Fernández-Gutiérrez, A. Metabolite profiling and quantification of phenolic compounds in methanol extracts of tomato fruit. Phytochemistry 2010, 71, 1848-1864. [CrossRef] [PubMed]

51. Razeq, F.M.; Kosma, D.K.; França, D.; Rowland, O.; Molina, I. Extracellular lipids of Camelina sativa: Characterization of cutin and suberin reveals typical polyester monomers and unusual dicarboxylic fatty acids. Phytochemistry 2021, 184, 112665. [CrossRef]

52. Chen, C.Y.; Lin, R.J.; Huang, J.C.; Wu, Y.H.; Cheng, M.J.; Hung, H.C.; Lo, W.L. Chemical constituents from the whole plant of Gaultheria itoana Hayata. Chem. Biodivers. 2009, 6, 1737-1743. [CrossRef]

53. Davini, E.; Esposito, P.; Iavarone, C.; Trogolo, C. Structure and configuration of unedide, an iridoid glucoside from Arbutus unedo. Phytochemistry 1981, 20, 1583-1585. [CrossRef] 
54. Zhang, Y.; Liu, L.; Gao, J.; Wu, C.; Han, L.; Liu, E.; Shi, P.; Gao, X.; Wang, T. New secoiridoids from the fruits of Ligustrum lucidum Ait with triglyceride accumulation inhibitory effects. Fitoterapia 2013, 91, 107-112. [CrossRef]

55. Dai, L.-P.; Zhang, L.-X.; Liu, Y.-L.; Wu, H.; Liu, R.-X.; Zhao, M.; Tian, S.-S.; Jiang, X.; Chen, S.-Q. Isolation and purification of diterpenoids from the aerial parts of Isodon excisoides target-guided by UPLC-LTQ-Orbitrap-MS. Nat. Prod. Res. 2018, 32, $2424-2430$. [CrossRef]

56. Bozov, P.I.; Coll, J. Neo-Clerodane Diterpenoids from Scutellaria altissima. Nat. Prod. Commun. 2015, 10, 13-16. [CrossRef]

57. Wang, Q.; Wei, T.; Zhou, X. Inhibitory Effects of Cortex Dictamni Aqueous Extract on Dipeptidyl Peptidase I and Chymase Activities and the Screening of Active Ingredients in Cortex Dictamni Based on Molecular Docking Technique. J. Biol. Life Sci. 2021, 12, 19-30. [CrossRef]

58. Quesada-Romero, L.; Fernández-Galleguillos, C.; Bergmann, J.; Amorós, M.-E.; Jiménez-Aspee, F.; González, A.; Simirgiotis, M.; Rossini, C. Phenolic Fingerprinting, Antioxidant, and Deterrent Potentials of Persicaria maculosa Extracts. Molecules 2020, $25,3054$. [CrossRef] [PubMed]

59. Mcdougall, G.J.; Austin, C.; Van Schayk, E.; Martin, P. Salal (Gaultheria shallon) and aronia (Aronia melanocarpa) fruits from Orkney: Phenolic content, composition and effect of wine-making. Food Chem. 2016, 205, 239-247. [CrossRef] [PubMed]

60. Bravo, K.; Alzate, F.; Osorio, E. Fruits of selected wild and cultivated Andean plants as sources of potential compounds with antioxidant and anti-aging activity. Ind. Crop. Prod. 2016, 85, 341-352. [CrossRef]

61. Colak, N.; Primetta, A.K.; Riihinen, K.R.; Jaakola, L.; Grúz, J.; Strnad, M.; Torun, H.; Ayaz, F.A. Phenolic compounds and antioxidant capacity in different-colored and non-pigmented berries of bilberry (Vaccinium myrtillus L.). Food Biosci. 2017, 20, 67-78. [CrossRef]

62. Céspedes, C.L.; Valdez-Morales, M.; Avila, J.G.; El-Hafidi, M.; Alarcón, J.; Paredes-López, O. Phytochemical profile and the antioxidant activity of Chilean wild black-berry fruits, Aristotelia chilensis (Mol) Stuntz (Elaeocarpaceae). Food Chem. 2010, 119, 886-895. [CrossRef]

63. Cásedas, G.; Les, F.; González-Burgos, E.; Gómez-Serranillos, M.P.; Smith, C.; López, V. Cyanidin-3-O-glucoside inhibits different enzymes involved in central nervous system pathologies and type-2 diabetes. South Afr. J. Bot. 2019, 120, 241-246. [CrossRef]

64. Llorent-Martínez, E.J.; Zengin, G.; Lobine, D.; Molina-García, L.; Mollica, A.; Mahomoodally, M.F. Phytochemical characterization, in vitro and in silico approaches for three Hypericum species. New J. Chem. 2018, 42, 5204-5214. [CrossRef]

65. Nile, A.; Gansukh, E.; Park, G.S.; Kim, D.H.; Hariram Nile, S. Novel insights on the multi-functional properties of flavonol glucosides from red onion (Allium cepa L) solid waste-In vitro and in silico approach. Food Chem. 2021, 335, 127650. [CrossRef] [PubMed]

66. Beara, I.N.; Torović, L.D.; Pintać, D.; Majkić, T.M.; Orčić, D.Z.; Mimica-Dukić, N.M.; Lesjak, M.M. Polyphenolic profile, antioxidant and neuroprotective potency of grape juices and wines from Fruška Gora region (Serbia). Int. J. Food Prop. 2018, 20, S2552-S2568. [CrossRef]

67. Tkacz, K.; Wojdyło, A.; Turkiewicz, I.P.; Ferreres, F.; Moreno, D.A.; Nowicka, P. UPLC-PDA-Q/TOF-MS profiling of phenolic and carotenoid compounds and their influence on anticholinergic potential for AChE and BuChE inhibition and on-line antioxidant activity of selected Hippophaë rhamnoides L. cultivars. Food Chem. 2019, 309, 125766. [CrossRef]

68. Budryn, G.; Grzelczyk, J.; Jaśkiewicz, A.; Żyżelewicz, D.; Pérez-Sánchez, H.; Cerón-Carrasco, J.P. Evaluation of butyrylcholinesterase inhibitory activity by chlorogenic acids and coffee extracts assed in ITC and docking simulation models. Food Res. Int. 2018, 109, 268-277. [CrossRef]

69. Alam, F.; Saqib, Q.N.U.; Shah, A.J.; Ashraf, M.; Al Ain, Q. Gut modulatory and butyrylcholinesterase inhibitory activities of Gaultheria trichophylla. Pharm. Biol. 2016, 54, 2917-2921. [CrossRef]

70. Salehi, B.; Sharifi-Rad, J.; Cappellini, F.; Reiner, Ž.; Zorzan, D.; Imran, M.; Sener, B.; Kilic, M.; El-Shazly, M.; Fahmy, N.M.; et al. The Therapeutic Potential of Anthocyanins: Current Approaches Based on Their Molecular Mechanism of Action. Front. Pharmacol. 2020, 11, 1300. [CrossRef] [PubMed]

71. Viegas, O.; Faria, M.A.; Sousa, J.B.; Vojtek, M.; Gonçalves-Monteiro, S.; Suliburska, J.; Diniz, C.; Ferreira, I.M.P.L.V.O. Delphinidin3-O-glucoside inhibits angiogenesis via VEGFR2 downregulation and migration through actin disruption. J. Funct. Foods 2019, 54, 393-402. [CrossRef]

72. León-González, A.J.; Sharif, T.; Kayali, A.; Abbas, M.; Dandache, I.; Etienne-Selloum, N.; Kevers, C.; Pincemail, J.; Auger, C.; Chabert, P.; et al. Delphinidin-3-O-glucoside and delphinidin-3-O-rutinoside mediate the redox-sensitive caspase 3-related pro-apoptotic effect of blackcurrant juice on leukaemia Jurkat cells. J. Funct. Foods 2015, 17, 847-856. [CrossRef]

73. Li, Y.; Li, X.; Cuiping, C.; Pu, R.; Weihua, Y. Study on the Anticancer Effect of an Astragaloside- And Chlorogenic Acid-Containing Herbal Medicine (RLT-03) in Breast Cancer. Evid. Based Complement. Altern. Med. 2020, 2020, 1515081. [CrossRef]

74. Cincin, Z.B.; Unlu, M.; Kiran, B.; Bireller, E.S.; Baran, Y.; Cakmakoglu, B. Molecular mechanisms of quercitrin-induced apoptosis in non-small cell lung cancer. Arch. Med. Res. 2014, 45, 445-454. [CrossRef]

75. Tang, S.M.; Deng, X.T.; Zhou, J.; Li, Q.P.; Ge, X.X.; Miao, L. Pharmacological basis and new insights of quercetin action in respect to its anti-cancer effects. Biomed. Pharmacother. 2020, 121, 109604. [CrossRef] [PubMed]

76. Li, Y.; Wang, Z.; Jin, J.; Zhu, S.X.; He, G.Q.; Li, S.H.; Wang, J.; Cai, Y. Quercetin pretreatment enhances the radiosensitivity of colon cancer cells by targeting Notch-1 pathway. Biochem. Biophys. Res. Commun. 2020, 523, 947-953. [CrossRef] [PubMed] 
77. Imran, M.; Iqubal, M.K.; Imtiyaz, K.; Saleem, S.; Mittal, S.; Rizvi, M.M.A.; Ali, J.; Baboota, S. Topical nanostructured lipid carrier gel of quercetin and resveratrol: Formulation, optimization, in vitro and ex vivo study for the treatment of skin cancer. Int. J. Pharm. 2020, 587, 119705. [CrossRef]

78. Teekaraman, D.; Elayapillai, S.P.; Viswanathan, M.P.; Jagadeesan, A. Quercetin inhibits human metastatic ovarian cancer cell growth and modulates components of the intrinsic apoptotic pathway in PA-1 cell line. Chem. Biol. Interact. 2019, 300, 91-100. [CrossRef] [PubMed]

79. Ni, G.; Tang, Y.; Li, M.; He, Y.; Rao, G. Synthesis of scutellarein derivatives with a long aliphatic chain and their biological evaluation against human cancer cells. Molecules 2018, 23, 310. [CrossRef] [PubMed] 